School of Finance

University of St.Gallen

SYSTEMIC RISK IN THE INSURANCE SECTOR: REVIEW AND DIRECTIONS FOR FUTURE RESEARCH

MARTIN ELING

DAVID PANKOKE

WORKING PAPERS ON FINANCE NO. 2014/21

INSTITUTE OF INSURANCE ECONOMICS (I.VW - HSG)

NOVEMBER 2014 


\title{
Systemic Risk in the Insurance Sector: Review and Directions for Future Research $^{*}$
}

November 2014

\begin{abstract}
This paper reviews the extant research on systemic risk in the insurance sector and outlines new areas of research in this field. We summarize and classify 43 theoretical and empirical research papers from both academia and practitioner organizations. The survey reveals that traditional insurance activity in the life, non-life, and reinsurance sectors neither contributes to systemic risk, nor increases insurers' vulnerability to impairments of the financial system. However, non-traditional activities (e.g., CDS underwriting) might increase vulnerability and life insurers might be more vulnerable than non-life insurers due to higher leverage. Whether non-traditional activities also contribute to systemic risk is not entirely clear; however, the activities with the potential to contribute to systemic risk include underwriting financial derivatives, providing financial guarantees, and short-term funding. This paper is of interest not only to academics, but is also highly relevant for the industry, regulators, and policymakers.
\end{abstract}

Keywords: Systemic Risk; Insurance; Solvency II; Financial Crisis

Authors: Martin Eling, martin.eling@unisg.ch; David Pankoke, david.pankoke@unisg.ch Institute of Insurance Economics, University of St. Gallen, Kirchlistrasse 2, 9010 St. Gallen, Switzerland 


\section{Introduction}

In the wake of the financial crisis and the collapse of Lehman Brothers and AIG, systemic risk has been widely discussed in the financial services sector. A number of research papers on the subject have been published, and reports have been issued by regulators and industry think-tanks. Recently, the Financial Stability Board (FSB) published a list of nine global systemically important insurers and intends to implement several special policy measures for these institutions by January $2019 .^{1}$

A more detailed review of the work already done on this topic and a look at what remains to be investigated is worthwhile for at least two reasons. First, researchers document that certain business activities might contribute to systemic risk in the insurance sector. A structured review can identify those activities and the situations under which they may be cause for alarm. Second, the literature shows mixed results regarding systemic risk, for example, in the case of reinsurance, which calls for a structured review of what has been studied to date and what remains to be done to settle this issue.

This paper makes three contributions to the ongoing discussion. First, we discuss how systemic risk can be understood conceptually and how it can (or cannot) be measured. Second, based on this framework, we review the literature on systemic risk in the insurance sector. Third, we highlight areas in need of more research. The survey is intended to enhance understanding of systemic risk in the insurance sector and also motivate more research in this field. The literature indicates that policymakers and regulators need to closely analyse systemic risk, especially with respect to non-traditional insurance activities.

The remainder of the paper is organised as follows. We start by discussing the definition and classification of systemic risk as well as systemic risk measures. Subsequently, we review the extant insurance literature on systemic risk and summarize the main results for different lines and activities of insurance companies. After that we investigate whether banking

1 See FSB (2013a). The FSB is an international organization that was established by the G-20 in April 2009. Its purpose is to monitor the finance industry and make to recommendations for addressing systemic risk. 
regulation should be extended to insurance companies. We close the article with a conclusion and a discussion of future research directions.

\section{Classification of Systemic Risk}

The financial system can be thought of as a network with two kinds of nodes (financial institutions and non-financial actors having business relations with financial institutions) and edges (business activities). ${ }^{2}$ To identify the origins of a possible impairment and the contributors to systemic risk, one can focus on the nodes, the edges, or both.

Regulators focus on the nodes and try to identify those institutions most likely to cause an impairment of the financial system. As a regulatory response to the financial crisis, the FSB initially suggested three criteria for evaluating whether a financial institution is systemically relevant: size, interconnectedness, and substitutability. ${ }^{3}$ According to the FSB/IAIS, these criteria should be used to identify companies, not business activities, which can impair the financial system. ${ }^{4}$

Another branch of the literature focuses on the edges of the network, or the business activities of institutions, in attempting to identify possible origins of financial system impairment (see Geneva Association, 2010a). We follow this strand of literature, arguing that it is the more appropriate approach for regulatory purposes and for understanding systemic risk of the financial industry.

From a regulatory perspective, business activities should be considered because otherwise regulatory arbitrage-the migration of risky business activities from highly regulated institutions to less regulated ones—is likely. Market distortions can occur because distressed systemically important financial institutions (SIFIs) are likely to be bailed out and therefore have a competitive advantage over non-SIFIs (see, e.g., Keller, 2011; Kessler, 2013).

\footnotetext{
See, e.g., Anand et al. (2013).

Subsequently, the FSB (2009) and IAIS (2013a) added global activity and non-traditional insurance to this list.

4 Recently, nine insurance companies and 28 banks were identified as systemically important financial institutions (SIFIs); see FSB (2012, 2013a).
} 
When it comes to understanding systemic risk, the activity-based view also has advantages because, in most cases, it is not the whole institution that contributes to systemic risk, but only certain of its activities. ${ }^{5}$ Furthermore, applying the systemic risk criteria to institutions can be misleading. For example, the size of an insurance company does not necessarily increase systemic risk if the company has a well-diversified underwriting portfolio. In fact, the insurance company business model is based on the underwriting and pooling of uncorrelated idiosyncratic risks. As long as the size of a certain business line is not the result of risk concentration, but instead a manifestation of the law of large numbers, there should be no increased potential for systemic risk (see, e.g., IAIS, 2011, 2012a; Kessler, 2013).

It is important not only to identify which parts of the financial system can originate impairment and contribute to systemic risk, but also to discover which parts are most vulnerable to impairment. If the financial system is thought of as a network, it is plausible that both nodes (institutions) and edges (business activities) can be vulnerable.

In the remainder of the paper, we use the term 'contribution to systemic risk' for an institution or business activity that increases systemic risk. We use 'vulnerability' when describing those parts of the financial system that are most vulnerable to impairment. ${ }^{6}$

\section{Systemic Risk Definitions}

There is no generally agreed-upon definition of 'systemic risk' other than that it involves uncertainty about the occurrence of a specific event. ${ }^{7}$ We reviewed 26 definitions of systemic risk and identified three important elements:

5 For example, the AIG financial services division was not regulated by the framework applicable to insurers despite its very risky business model. Only the much less riskier parts of AIG were subject to insurance regulation, and thus the company's severe systemic risk was not visible. See Harrington (2009), Brady (2009), and Acharya et al. (2011).

6 Our classification is similar to the 'contribution approach' and 'participation approach' defined by Tarashev et al. (2010) and used by Drehmann and Tarashev (2011) and Jobst (2012). We do not use that terminology here because, for our purposes, it is too narrow. Both approaches consider only institutions and bankruptcies and ignore, for example, institutions that are in distress, but not insolvent, as well as business activities. Our approach is also employed by others, for example, Klein (2013).

7 Note that according to risk theory, the term 'risk' is misleading since it implies that the probability of the occurrence of an event is measurable and exactly known. In contrast, 'uncertainty' implies that the 
- Risk of an event: For each risk there must be an associated event that can occur. The associated event is the dysfunction of financial services, default of financial institutions, or a shock to the economy. ${ }^{8}$

- Impact of the event: Most definitions specify the consequences if the event occurs, which is usually that the real economy is negatively affected.

- Causation of the event: Some definitions require the risk to have a certain causation before it is labelled systemic. These causations can be general in nature and/or specific ${ }^{9}$ and are mostly related to the financial services sector.

The variety of definitions makes obvious the enormous difficulty involved in differentiating between cause, impact, and events when discussing systemic risk. ${ }^{10}$ Thus, it is not surprising that, to date, no agreement on the definition of systemic risk has been reached. ${ }^{11}$ However, most of the definitions considered in this paper refer to the 2008 financial crisis, ${ }^{12}$ and it thus might be useful to look at the events of 2008 as a means of differentiating systemic risk from other risks.

- Event: Certain financial services became unavailable (e.g., inter-bank lending) or had virtually no market (e.g., credit).

- Impact of the event: As a consequence, there was a substantial negative effect on the economy.

probability of the occurrence of an event is not measurable and not exactly known. Most scholars base their definition of uncertainty and risk on Knight (1921). See, e.g., Tversky and Kahneman (1992), Camerer and Weber (1992), and Zweifel and Eisen (2012). In the following, for the sake of simplicity, we use the term 'risk' as it is used in the systemic risk literature.

8 The first two aspects refer to financial services; the latter event involves the general economy. We use 'financial instability' as a synonym for 'dysfunction of financial services'. It must be kept in mind that neither financial 'stability' nor 'instability' have clear-cut definitions. See, e.g., Allen and Wood (2006), European Central Bank (2013), and Federal Reserve Bank of Cleveland (2013).

9 Klein (2011) writes that idiosyncratic events (e.g., the failure of a single entity or cluster of entities) or general conditions in financial intermediaries might cause systemic risk. The general conditions are related to the linkages between financial institutions, which can lead to a cascading effect of bankruptcies, especially in the case of excessive risk taking.

10 For example, it is not clear whether the shock to the real economy is the event or the consequence of the event. Similarly, it is far from clear whether default of institutions is the event or the causation of an event.

11 See, e.g., Liedtke (2010) and Dwyer (2009) for a critical discussion of several definitions of systemic risk.

12 See, e.g., Bach and Nguyen (2012), Billio et al. (2012), and Rodríguez-Moreno and Peña (2013). 
- Causation of the event: In 2008, an external shock (falling prices in the U.S. subprime mortgage market) impaired several financial institutions. Due to contagion and interdependence, other financial institutions and services became impaired as well.

An appropriate definition should encompass all risks that can lead to the reoccurrence of the 2008 crisis and exclude all others. It is this last point that is usually ignored in many studies. An exception is the concept of systemic risk proposed by De Bandt and Hartmann (2000), which distinguishes between risks of shocks based on their second-round effects (the focus is not on institutions affected by the shock, but on the consequences of these institutions being impaired due to the shock). In these authors' view, only when most institutions or markets would be affected indirectly and fail is the risk systemic. In addition, Harrington (2009) distinguishes systemic risk from the risk of common shocks. According to him, only the risk of an event that involves 'interdependency-transmitted contagion' should be labelled systemic. In general, we argue that a systemic risk definition should be judged against the following criteria:

- Risk of an event: The definition should address the dysfunction of financial services. Mandating that the event must involve simultaneous default of institutions or contagion effects would result in too narrow a definition of systemic risk, since such events can conceivably occur without the financial services sector becoming dysfunctional.

- Impact of the event: The definition should include that the event has to cause a substantial negative impact on the real economy. The term 'substantial negative impact on the real economy' is important since without this level of specificity the definition could cover insignificant events. The term 'substantial' should be understood in terms of severity. Furthermore, the negative impact must be a definite consequence of the occurring event. Otherwise, as Liedtke (2010) points out, the risks of wars, floods, and diseases would also be systemic risks, making the definition too broad to be useful. 
- Causation of the event: Likewise, unless causation of the risk is included, the definition will again be too broad. For example, without putting some limits on 'causation', the risk that the regulator will issue a regulation that impairs financial services with the consequence that the real economy is affected could be labelled a systemic risk. However, the limits on causation must not be too narrow either. For example, some definitions only consider as systemic the risk of a certain event caused by the impairment of a few institutions that starts a chain reaction (e.g., Csiszar, 2002; Adrian and Brunnermeier, 2011; Billio et al., 2010, 2012). However, these definitions fail to consider the situation where one shock affects the entire financial services industry. Basically, it is important that the definition makes clear that systemic risk emerges within the financial system. For a more detailed discussion of system-wide shock versus contagion, see 'Types of Impairments' in the Appendix.

\section{Systemic Risk Measures}

There is no common definition of systemic risk, so there is no standard for systemic risk measures and the literature cannot agree on one specific measure. ${ }^{13}$ Broadly, there are two strands of literature, one dealing with macro- and the other with microprudential systemic risk measures. Macroprudential measures attempt to access systemic risk at the level of the whole economy; microprudential measures are used to discover individual institutions that contribute most to systemic risk or are especially vulnerable to an impairment of the financial system. The studies we reviewed for this paper focus on microprudential measures. The most common measures are shown in Table 1.

\footnotetext{
${ }^{13}$ Bisias et al. (2012) provide a broad overview and explanation of currently discussed systemic risk measures.
} 


\begin{tabular}{|c|c|c|c|}
\hline Systemic Risk Measure & Description & Focus & Reference \\
\hline BANKBETA & $\begin{array}{l}\text { Measures linkages between stock returns and the } \\
\text { portfolio returns of the banking sector. }\end{array}$ & $\begin{array}{l}\text { Interconnection } \quad \text { between } \\
\text { institutions (interdependence) }\end{array}$ & Chen et al. (2013) \\
\hline$\Delta \mathrm{CoVaR}$ & $\begin{array}{l}\text { Measures the impact of a certain institution's } \\
\text { distress on the value at risk of the financial system. }\end{array}$ & $\begin{array}{l}\text { Interconnection between } \\
\text { institutions (contagion) }\end{array}$ & $\begin{array}{l}\text { Adrian and } \\
\text { Brunnermeier (2011) }\end{array}$ \\
\hline $\begin{array}{l}\text { DIP (distressed insurance } \\
\text { premium) }\end{array}$ & $\begin{array}{l}\text { Measures the price of insurance against financial } \\
\text { distress based on asset return calculations and } \\
\text { default probabilities of individual institutions. }\end{array}$ & $\begin{array}{lrr}\begin{array}{l}\text { Market } \\
\text { against }\end{array} & \begin{array}{r}\text { price of insurance } \\
\text { default }\end{array} & \\
\text { definstitution's }\end{array}$ & Huang et al. (2009) \\
\hline LRMES & $\begin{array}{l}\text { Measures the long-run marginal expected shortfall } \\
\text { of a company's return in the event of a financial } \\
\text { crisis. }\end{array}$ & Shortfall in times of crisis & Engle et al. (2014) \\
\hline $\begin{array}{l}\text { LTD (lower tail } \\
\text { dependence) }\end{array}$ & $\begin{array}{l}\text { Measures the probability that an observation of } \\
\text { stock returns' joint distribution will lie in the } \\
\text { distribution's lower tail. }\end{array}$ & $\begin{array}{l}\text { Interconnection between } \\
\text { institutions (contagion) }\end{array}$ & Weiß et al. (2012) \\
\hline $\begin{array}{l}\text { Granger-causality } \\
\text { networks }\end{array}$ & $\begin{array}{l}\text { Measures Granger-causality between the stock } \\
\text { market returns of institutions. }\end{array}$ & $\begin{array}{l}\text { Interconnection between } \\
\text { institutions (interdependence) }\end{array}$ & Billio et al. (2012) \\
\hline $\begin{array}{l}\text { MES (marginal expected } \\
\text { shortfall) }\end{array}$ & $\begin{array}{l}\text { Measures the stock return of a company when the } \\
\text { entire equity market is in a downturn. }\end{array}$ & Shortfall in times of crisis & Acharya et al. (2012b) \\
\hline SRISK & $\begin{array}{l}\text { Measures the capital a company needs if there is a } \\
\text { crisis. }\end{array}$ & Shortfall in times of crisis & Acharya et al. (2012a) \\
\hline
\end{tabular}

Table 1: Systemic risk measures applied to the insurance sector

BANKBETA, $\triangle$ CoVaR, LTD, and Granger-causality networks focus on the interconnection of institutions in normal times (interdependence) as well as in times of crisis (contagion). They are based on the assumption that the institutions that are highly interconnected contribute most to systemic risk. Naturally, the studies endorsing these measures use a definition of systemic risk that focuses on contagion effects. ${ }^{14}$ LRMES, MES, and SRISK (and, to a certain extent, DIP) measure the impact of a crisis on an institution and do not capture contagion effects. Therefore, work focusing on LRMES, MES, or SRISK does not consider interrelations between institutions as crucial for systemic risk. ${ }^{15}$ Some differences in the literature are due to the definition of systemic risk used and the measure employed to measure it, as we show in the following section. Generally, though, the first group of measures assesses contribution to systemic risk, whereas the second one assesses the vulnerability of an institution (see Chen et al., 2013; Cummins and Weiss, 2013; Weiß and Mühlnickel, 2014).

Nevertheless, even if the characteristics of the systemic risk measures are kept in mind there is still plenty of room for improvements. The most fundamental criticism is presented by Benoit at al. (2013). They argue that $\triangle \mathrm{CoVaR}$, MES, and SRISK have no advantages over

${ }^{14}$ See Chen et al. (2013), Adrian and Brunnermeier (2011), and Billio et al. (2012). Summaries of these authors' understanding of systemic risk are set out in Table A1 in the Appendix.

15 See, e.g., Acharya et al. (2011). 
traditional market risk measures. For a U.S. sample of 2,000 financial institutions they show that identifying systemically important institutions by $\Delta \mathrm{CoVaR}$ leads to the same results as using Value at Risk. Similarly, MES can be substituted for by market beta and SRISK by leverage in normal times or liabilities in times of crisis. The authors conclude 'that these measures fall short in capturing the multifaceted nature of systemic risk' (Benoit at al., 2013). Another, more practical, shortcoming of these systemic risk measures is that they only provide information about the relative contribution to systemic risk/vulnerability of an institution; absolute risk remains unknown. In boom times, even the most significant systemically relevant institution might not be a problem, whereas in times of crisis, even events at an institution which is no. 28 in line could be cause for concern. 


\section{Systemic Risk in the Insurance Sector}

One of the first institutions hit by the financial crisis was AIG. Several bailout programs were instituted to prevent its insolvency. AIG received the first rescue funds in September 2008 and by July 2009, US\$135 billion had been spent on the company. ${ }^{16}$ Against this background, it is reasonable to ask whether and, if so, to what extent insurers and their business activities contribute to systemic risk. ${ }^{17}$

We thus discuss the different business activities of insurance companies and look at how certain activities contribute to systemic risk. Furthermore, we evaluate which business activities and which kinds of insurers are vulnerable to an impairment of the financial system. Our assessment of systemic risk in the insurance industry is based on the studies listed in Table 2. These were selected from five sources: peer-reviewed journal articles, working papers, reports by international government organisations or regulators, books or chapters in books, and industry reports.

It is important to consider the source of a study when interpreting its results. For example, industry reports typically take an industry perspective, whereas peer-reviewed journal articles are usually more neutral, seeing as they typically are written by independent academics and undergo independent review before publication. We put most weight on the findings from the peer-reviewed journal articles, but think it is important to also present the results of industry studies. ${ }^{18}$ Where our results are based on work coming from an industry perspective, we explicitly mention this fact so that this report is as unbiased and neutral as possible. To make sure that all relevant studies are included, we used a search strategy based on Biener and Eling (2012).

16 See Harrington (2009).

17 Harrington (2009) and Baranoff (2012) show that the AIG bailout is not a good case for studying the systemic risk contribution of a standard insurer, since traditional insurance activities were not responsible for the crisis. In this paper we identify more generally which business activities do or do not contribute to systemic risk and increase vulnerability to impairments of the financial system.

18 Of course, authors of peer-reviewed journal articles also might take an industry perspective, e.g., Kessler (2013), who is CEO of the insurance company SCOR. 


\begin{tabular}{|l|l|}
\hline Type of Source & Study: \\
\hline $\begin{array}{l}\text { Peer-reviewed journal } \\
\text { articles }\end{array}$ & $\begin{array}{l}\text { Trichet (2005), Harrington (2009), Baluch et al. (2011), Van Lelyveld et al. (2011), Besar et al. (2011), Bach } \\
\text { and Nguyen (2012), Billio et al. (2012), Baranoff (2012), Kessler (2013), Chen et al. (2013a), Weiß and } \\
\text { Mühlnickel (2014), Cummins and Weiss (2014), Engle et al. (2014), Berry-Stölzle et al. (2014), Park and Xie } \\
\text { (2014) }\end{array}$ \\
\hline Working papers & $\begin{array}{l}\text { Radice (2010), Cummins and Weiss (2013), Grace (2011), Harrington (2011), Cummins et al. (2012), Neale et } \\
\text { al. (2012), Jobst (2012), Weiß et al. (2013), Weiß and Mühlnickel (2013), Grace et al. (2013), Chen et al. (2013, } \\
\text { 2013b), Baranoff et al. (2013) }\end{array}$ \\
\hline $\begin{array}{l}\text { Books/chapter in books } \\
\text { government } \\
\text { organisations/regulators }\end{array}$ & Acharya et al. (2011), Klein (2013) \\
\hline $\begin{array}{l}\text { Industry reports } \\
\text { Zufferey (2000), FSB (2009), IAIS (2009, 2010, 2011, 2012a, 2012b) }\end{array}$ \\
\hline
\end{tabular}

Table 2: Reviewed studies on systemic risk in insurance classified by source

Table 3 provides an overview of insurance activities and their systemic risk potential. The structure of the table is similar to that employed by the IAIS in classifying insurance activities (see IAIS, 2011) and by the Geneva Association (2010a). ${ }^{19}$ In our view, insurance activities are either related to underwriting or funding and investing processes. We define as underwriting related all activity that has as its purpose in the transfer of a risk to the insurer from a third party in exchange for a fee. Therefore, we understand not only the transfer of life and non-life risks as underwriting, but also reinsurance and all kinds of alternative risk transfer products. ${ }^{20}$ We define funding and investing processes as all activities with the purpose of increasing investment income and ensuring that liabilities are met. This includes not only investment of premium income and asset liability management (see, e.g., Rejda and MacNamara, 2014, chapters 6 and 7; Zweifel and Eisen, 2012, chapter 1.4), but also profitenhancing activities as described by the Geneva Association (2010a, chapter 3.4.1). ${ }^{21}$ Furthermore, we differentiate business activities according to their degree of innovation, thus classifying them as either traditional or non-traditional insurance business. This classification is not always clear cut but, in general, we consider an activity to be traditional when its accompanying risks are mostly (a) idiosyncratic, (b) not correlated with each other, and (c)

19 It is important to note that the classification of insurance activities in Table 3 is not meant to be a final assessment, but more a framework for evaluating the systemic risk of insurance. Therefore, the classification of a certain activity could be arguable; for example, compare IAIS (2013b).

20 Compare with Rejda and McNamara (2014, chapter 6), who distinguish between underwriting and reinsurance. Using their framework, we consider all risk transfer activities as underwriting within life insurance, health insurance, and property and liability insurance, as well as reinsurance.

21 The non-insurance activity of CDS underwriting, as mentioned by IAIS (2011), belongs, according to our definition, to the underwriting processes, whereas capital market business, banking, and third-party asset management are funding and investing processes. 
not influenced by economic business cycles (see IAIS, 2012b). ${ }^{22}$ Using this classification system, we identify papers that discuss a particular business model and evaluate that business model's contribution to systemic risk and its vulnerability to impairments of the financial system.

A list and summary of all studies reviewed for this analysis can be found in Table A2 in the Appendix. In that table, we distinguish between academic work published in scientific journals or as a working paper and more applied work by industry associations and regulators. $^{23}$

We already mentioned some limitations of systemic risk measures and why the results of studies using these measures are contentious. Before discussing the literature in detail, it seems worthwhile to point out another general shortcoming of all empirical studies we reviewed: the considered time horizons are very short. For example, no empirical study takes the time of the Great Depression in the United States during the late 1920s and early 1930s into account. This is understandable, given data availability issues, but in order to make assessments about infrequent events like systemic crises, one needs to look across centuries, not just decades. ${ }^{24}$

22 For example, many market participants (especially in German-speaking countries) view life insurance contracts with embedded guarantees as their traditional business model. According to our classification, however, guaranteed annuities are non-traditional since they are influenced by the economic business cycle. In this context, we also discuss modern variable annuities with different types of guarantees.

23 In Table A2 we also categorise the papers according to the methodology employed. Most papers are qualitative discussion papers (27 papers), but some take a quantitative approach (16 papers). For the quantitative papers, we explain the underlying methodology in more detail, i.e., the use of event studies, systemic risk measurement calculation, or regression analysis.

24 Basically, we share the opinion of Taylor (2012). 


\begin{tabular}{|c|c|c|c|c|c|}
\hline $\begin{array}{l}\text { Pro- } \\
\text { cess }\end{array}$ & \multicolumn{2}{|r|}{ Business Activity } & $\begin{array}{l}\text { Systemic Risk } \\
\text { Contribution }\end{array}$ & \begin{tabular}{|l|} 
Company’s \\
Vulnerability
\end{tabular} & Rationale \& Source \\
\hline \multirow{2}{*}{ 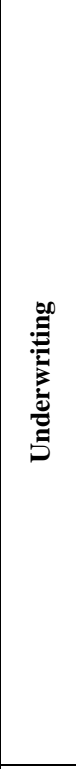 } & $\begin{array}{l}\text { Tra- } \\
\text { ditional }\end{array}$ & $\begin{array}{l}\text { Life } \\
\text { - Life insurance } \\
\text { - Annuities } \\
\text { Non-Life } \\
\text { - Health insurance } \\
\text { - Property \& casualty } \\
\text { insurance } \\
\text { - Liability insurance } \\
\text { - Legal insurance } \\
\text { Reinsurance }\end{array}$ & $\begin{array}{l}\text { Very low } \\
\text { (all studies } \\
\text { agree there is no } \\
\text { systemic risk } \\
\text { contribution) }\end{array}$ & \begin{tabular}{|l} 
Very low \\
(there is no \\
study arguing \\
that non- \\
market risks \\
are influenced \\
by an \\
impairment of \\
the financial \\
system)
\end{tabular} & $\begin{array}{l}\text { - Between life, non-life sector, and banks, interconnectedness (counterparty credit risk/cross-holdings) is low; between reinsurance companies and primary } \\
\text { insurers, the relation is hierarchical (e.g., Zufferey, 2000; Baur et al., 2003; Trichet, 2005; Baluch et al., 2011; IAIS, 2011, 2012b; Cummins and Weiss 2013; } \\
\text { Grace et al., 2013; Kessler, 2013) } \\
\text { - A reinsurance retrocession spiral affects the insurance sector but not the rest of the economy (e.g., Geneva Association, 2010a; Cummins and Weiss, 2013, 2014) } \\
\text { - Claims are contingent on loss events and therefore an 'insurance run’ is not possible (e.g., Radice, 2010; Baluch et al., 2011; Cummins and Weiss, 2014; Geneva } \\
\text { Association, 2012; Kessler, 2013) } \\
\text { - Cash outflow if loss events occur is slow (e.g., Cummins and Weiss, 2014; Jobst, 2012; Kessler, 2013) } \\
\text { - Entry barriers are low and classical insurance activities are substitutable as long as insurability is given, e.g., via alternative risk transfer and self-insurance, or its } \\
\text { absence would not substantially affect the real economy (e.g., Baur et al., 2003; Geneva Association, 2010b; Cummins and Weiss, 2013, 2014; IAIS, 2012a) } \\
\text { - Primary insurers diversify their exposure to reinsurance (e.g., Baur et al., 2003; Geneva Association, 2010a; Baluch et al., 2011; Besar et al., 2011); however, } \\
\text { there are contrary views (e.g., Park and Xie, 2014, p. 10; IISS, 2012b) } \\
\text { - Studies show that bankruptcies of reinsurers would not lead to market failure (e.g., van Lelyveld et al., 2011; Park and Xie, 2014) } \\
\text { - Insurance is a necessary function for the economy (Bach and Nguyen, 2012), but individual insurance companies are substitutable (e.g., IAIS, 2011; Jobst, 2012) }\end{array}$ \\
\hline & $\begin{array}{l}\text { Non- } \\
\text { Tra- } \\
\text { ditional }\end{array}$ & $\begin{array}{l}\text { Life } \\
\text { - Annuities with } \\
\text { guarantees/variable } \\
\text { annuities } \\
\text { - Group annuities } \\
\text { - Separate accounts } \\
\text { Non-Life } \\
\text { - Credit insurance } \\
\text { - Financial guarantees } \\
\text { - CDSs/CDOs }\end{array}$ & \begin{tabular}{|l} 
Medium \\
(most studies \\
agree there is a \\
systemic risk \\
contribution)
\end{tabular} & \begin{tabular}{|l} 
High \\
(except for \\
credit \\
insurance, \\
studies agree \\
that these \\
activities \\
increase \\
vulnerability)
\end{tabular} & $\begin{array}{l}\text { - Life products with guarantees might exacerbate a crisis if assets have to be sold during a downturn (Geneva Association, 2011) } \\
\text { - Systemic risk measures give some indication that group annuities and separate accounts might create systemic rick (Cummins and Weiss, 2013) } \\
\text { - Credit insurance has no direct liquidity impact and has very limited volume (e.g., Baur et al., 2003; Geneva Association, 2010a) } \\
\text { - Financial guarantees impose market risk on insurance companies and can have a direct liquidity impact; they thus increase vulnerability to financial crisis (e.g., } \\
\text { Geneva Association, 2010a; IAIS, 2010; Cummins and Weiss, 2013, 2014; Chen et al., 2013) } \\
\text { - CDSs/CDOs have direct liquidity impact and make the selling party vulnerable to systemic crisis } \\
\text { - Majority view: contribution to systemic risk because CDS buyer faces counterparty risk if CDS seller defaults (e.g., Trichet, 2005; Geneva Association, 2010a; } \\
\text { Baluch et al., 2011; Klein, 2013; Grace, 2011; Baranoff, 2012; Chen et al., 2013; Cummins and Weiss, 2013) } \\
\text { - Minority view: no contribution to systemic risk because if CDS seller defaults, CDS buyer does not face direct liquidity impact (e.g., Radice, 2010; Wallison } \\
\text { reported by Harrington, 2009; cf. Harrington, 2011) }\end{array}$ \\
\hline \multirow{2}{*}{ 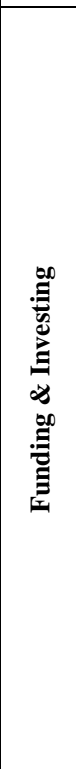 } & $\begin{array}{l}\text { Tra- } \\
\text { ditional }\end{array}$ & $\begin{array}{l}\text { Life, Non-Life, Reinsurance } \\
\text { - Premiums funding } \\
\text { - Asset liability management } \\
\text { \& hedging } \\
\text { - Liquidity management } \\
\text { - Insurance-linked securities } \\
\text { (catastrophe bonds) }\end{array}$ & $\begin{array}{l}\text { Very low } \\
\text { (all studies } \\
\text { agree there is no } \\
\text { systemic risk } \\
\text { contribution) }\end{array}$ & $\begin{array}{l}\text { Medium } \\
\text { (studies agree, } \\
\text { that except for } \\
\text { catastrophe } \\
\text { bonds, these } \\
\text { activities are } \\
\text { vulnerable; } \\
\text { however, the } \\
\text { risks are very } \\
\text { manageable) }\end{array}$ & $\begin{array}{l}\text { - Premiums are paid upfront for contingent claims; no risk caused by maturity mismatches (e.g., Trichet, 2005; Cummins and Weiss, 2014; Kessler, 2013) } \\
\text { - Contingent claims prohibit fire sale of assets in case of an insolvency (e.g., Cummins and Weiss, 2013; Kessler, 2013) } \\
\text { - In contrast to banks, insolvencies of insurers are lengthy and orderly processes (e.g., IAIS, 2009, 2010; Geneva Association, 2012) } \\
\text { - Relatively high equity levels in non-life and reinsurance; life insurers are more vulnerable to crisis due to higher leverage (e.g., Harrington, 2009; Chen et al., } \\
\text { 2013b) } \\
\text { - In many markets, high lapse fees for life products with saving components make immediate cash outflows unlikely (e.g., Radice, 2010; Geneva Association, } \\
\text { 2010b; Kessler, 2013); also, life insurers would have enough liquidity without the need to sell assets (Baranoff et al., 2013) } \\
\text { - Even during the financial crisis, external funding was available for life insurers (Berry-Stölzle et al., 2014) } \\
\text { - Limited fungibility of liquidity within insurance groups could lead to increased vulnerability in times of crisis (e.g., Radice, 2010; Baranoff, 2012) } \\
\text { - Compared to the market for financial derivatives, the market volume of alternative risk transfer products is small, the insurer remains liable, and the insurer keeps } \\
\text { a certain amount of the risk on its balance sheet (IAIS, 2011, 2012b); in particular, cat bonds help the underwriting issuer to diversify and decrease its } \\
\text { underwriting risk to catastrophes (e.g., Weiß et al., 2013; Kessler, 2013) }\end{array}$ \\
\hline & $\begin{array}{l}\text { Non- } \\
\text { Tra- } \\
\text { ditional }\end{array}$ & $\begin{array}{l}\text { Life } \\
\text { - Securitization of } \\
\text { embedded value in upfront } \\
\text { - } \text { paid commissions } \\
\text { Life, Non-term funding } \\
\text { - Securities lending } \\
\text { Non-Life, Reinsurance } \\
\text { - Credit rating utilization } \\
\text { - Industry-loss warranties }\end{array}$ & $\begin{array}{l}\text { Medium } \\
\text { (whether there is } \\
\text { a systemic risk } \\
\text { contribution is } \\
\text { unclear) }\end{array}$ & $\begin{array}{l}\text { High } \\
\text { (studies agree } \\
\text { that these } \\
\text { activities } \\
\text { increase } \\
\text { vulnerability) }\end{array}$ & $\begin{array}{l}\text { - Short-term funding can lead to fire sales if liquidity dries up, especially in the case of securities lending and credit rating utilization (e.g., Geneva Association, } \\
\text { 2010; Acharya et al., 2011; Besar et al., 2011; Jobst, 2012); however, it is also argued that securities lending does not contribute to systemic risk since } \\
\text { counterparties receive collateral (Baranoff, 2012) } \\
\text { - There is an interest rate risk for investors if securitized products contain (a) guarantees and/or (b) the discount factor is inadequate (IAIS, 2010, 2012b) } \\
\text { - Performance (stock market returns) of financial institutions is becoming increasingly interconnected (e.g., Acharya et al., 2011; Baluch et al., 2011; Cummins et } \\
\text { al., 2012; Billio et al., 2012; Weiß and Mühlnickel, 2014); however, banks still have a stronger impact on insurers than vice versa (e.g., Grace, 2011; Engle et al., } \\
\text { 2014; Chen et al., 2013a); this interrelation is mainly driven by non-traditional insurance activities (e.g., Neale et al., 2012; Cummins and Weiss, 2013) } \\
\text { - Exploitation of non-regulated subsidies and information asymmetries (e.g., Zufferey, 2000; Harrington, 2009; IAIS, 2010; Acharya et al., 2011; Baranoff, 2012) } \\
\text { - Not clear whether prices of alternative risk transfer products are uncorrelated with the financial market in times of crisis (IAIS, 2012b) } \\
\text { - Industry-loss warranties are not linked to an individual loss event, but cover the downturn of a whole industry, which can lead to an increased basis risk and credit } \\
\text { risk since there is no collateral (IAIS, 2012b) }\end{array}$ \\
\hline
\end{tabular}

Table 3: Evaluation of systemic risk of traditional and non-traditional insurance activities classified according to business processes 


\section{Systemic Risk in Traditional Insurance Underwriting}

Traditional insurance activities include underwriting life, health, property, accident, liability, and legal risks in the life and non-life sectors, as well as the transfer of risk via reinsurance.

The literature qualitatively assessing the systemic risk of business activities agrees that the systemic risk contribution of traditional non-life insurance (property, accident, liability, legal, and, in some jurisdictions, health) is very low due to low interconnectedness within the field and the fact that claims are bound to specific loss events that are in most cases independent from the business cycle. The major argument is that claims settlement can take several years. Thus, these activities contribute very little, if any, to systemic risk and do not increase the company's vulnerability to impairments of the financial system. This conclusion and line of reasoning is found in peer-reviewed journals as well as in reports by regulators and the industry. ${ }^{26}$

However, the results from two different strands of the literature cast some doubt on this conclusion. The first strand is represented by Billio et al. (2012) and Chen et al. (2013a). Both studies empirically show that the stock market returns of life as well as non-life insurers and banks have become more correlated in recent years. Billio et al. (2010) use monthly returns data from the 25 biggest U.S. hedge funds, brokers, and banks, as well as insurers, and test pairwise for Granger-causality. Basically, Chen et al. (2013b) do the same for 11 insurers and 22 banks in the United States; however, their analysis is not based on stock market returns, but on the Distressed Insurance Premium (DIP) measure. Both studies find that banks and insurers are interdependent, but that shocks in the banking industry affect insurers much more than vice versa. Thus, banks seem to contribute to systemic risk but insurers do not.

The second strand of literature calculates systemic risk measures directly for insurers. For example, Weiß and Mühlnickel (2013) apply LTD (lower tail dependence) as a systemic risk

26 See, e.g., Trichet (2005) and Cummins and Weiss (2014) (peer-reviewed journal articles), IAIS (2011) (regulator report), and Geneva Association (2010a) (industry association report). 
measure in an attempt to discover whether insurance mergers increase the contribution to systemic risk of an insurer. The authors only find slightly significant results for the North American banking sector, indicating that insurance mergers might affect the systemic risk contribution of banks. Generally, however, they find no evidence for increased systemic risk contribution due to M\&A activities in the insurance sector. Furthermore, Cummins and Weiss (2013) and Weiß and Mühlnickel (2013) show that, based on SRISK and MES, insurers are vulnerable to impairments of the financial system. However, these findings do not really contradict the results mentioned above because they focus on insurance companies, not specific business activities. Indeed, both studies conclude that the increased vulnerability is due to non-traditional insurance activities.

The Geneva Association (2010b) and Klein (2012), as well as Cummins and Weiss (2013, 2014), argue that there is no systemic risk from life insurance or annuities, either. Their main argument is that this line of business does not have a strong impact on other financial market participants or on the economy in general in the case of bankruptcy. Moreover, in most countries, customers are protected by guarantees. ${ }^{27}$ This is a convincing argument in view of the fact that there is no known case of a bankruptcy of a single life insurance company triggering a contagion effect and other insolvencies. The risks that led to insolvency in these cases were of an idiosyncratic nature (e.g., management failures). Radice (2010) supports this argument by pointing out that even the insolvency of very large life insurers might not contribute to systemic risk. Even if guarantees are not sufficient, policyholders do not suffer a total loss; instead, their claims will be reduced, as was the case with Equitable Life. Finally, as argued by the Geneva Association (2010a, 2010b), life insurance does not contribute to systemic risk for reasons having to do with time. The windup of an insurer is an orderly process and does not lead to an immediate default on liabilities, the fire sale of assets, or increased cash outflow. This view, in principle, is shared by the IAIS

27 See Geneva Association (2012), Harrington (2011), and Oxera (2007). 
(2012a), which assesses global systemically important insurers and puts only minor weight on traditional life and non-life underwriting activities.

Cummins and Weiss (2014) and Baluch et al. (2011) are more critical of reinsurers and mention that the reinsurance market is highly concentrated. There is high interconnection among reinsurers and between reinsurers and insurance companies. They argue that there is a danger of a retrocession spiral. Premiums are not only ceded between primary insurers and reinsurers, but also within the reinsurance industry and thus the bankruptcy of one reinsurer could trigger the bankruptcies of others. Similarly, the rating downgrade of a reinsurance company could trigger a chain reaction due to reinsurance contracts, which, typically, can be cancelled in such circumstances. This argument is presented by Park and Xie (2014), who show that up- and downgrades of reinsurers' ratings have an effect on primary insurers' ratings as well. However, scenario analyses by Park and Xie (2014) and Van Lelyveld et al. (2011) show that even the failure of several large reinsurers would result in only a few primary insurer insolvencies and therefore there is no contribution to systemic risk by reinsurers. Furthermore, Kessler (2013), too, argues that reinsurance does not contribute to systemic risk, since primary insurers diversify their counterparty risk to reinsurers. In addition, he states that retrocession spirals are unlikely due to a hierarchal market structure between reinsurers and primary insurers. This reasoning is in accordance with that of the IAIS (2012b) and the conclusions of a study by Swiss Re (see Baur et al., 2003). However, to our knowledge, there are no academic studies analysing such a hierarchical market structure. Cummins and Weiss (2013) argue that the failure of reinsurance companies could lead to problems within the insurance industry due to the connections between reinsurers and primary insurers, but they agree that reinsurance does not contribute to systemic risk since reinsurers ‘are not sufficiently interconnected with non-insurance institutions’. 
In this context, the question arises as to whether unavailability of insurance coverage is a systemic risk in the sense that the real economy is affected. The answer to this question is one on which academic studies, regulator reports, and industry association reports all agree and goes as follows. ${ }^{28}$ As long as the risk is quantifiable, insurance companies and their products are substitutable by other market participants and products, for example, by catastrophe bonds, due to low market entry barriers. Also, insurance coverage can be created within a certain industry in the form of a self-insurance cooperative. ${ }^{29}$ Furthermore, as long as an insurance business is profitable, there will be new market entries if there is demand and a shortage of supply.

In our opinion, the issue of the substitutability of an individual insurance company should not be confused with the situation where the whole insurance context changes. For example, after September 11, 2001, it was nearly impossible to obtain insurance coverage against terrorism. This situation was not due to an impairment of the financial system, but because the risk of terror attacks became unquantifiable. Therefore, there is no contribution to systemic risk since a link to the financial system is necessary for systemic risk.

\section{Systemic Risk in Non-Traditional Insurance Underwriting Activities}

As non-traditional insurance underwriting activities in the life segment we consider only annuities for which the insurer bears the investment risk and guarantees a certain payout. In the non-life sector, we classify credit insurance, financial guarantees, and financial derivatives underwriting as non-traditional activities.

Klein (2013), Cummins and Weiss (2014), IAIS (2011), and Grace (2011) point out that some aspects of guaranteed annuities could increase the issuing company's vulnerability in

28 See, e.g., Cummins and Weiss (2014) (peer-reviewed journal article), Radice (2010) (working paper), IAIS (2012a) (regulator report), and Geneva Association (2010b) (industry association report).

29 An example is the absence of industry liability insurance in 1984/1985 in the United States. Insurers had to excessively increase their provisions for potential claims due to asbestos hazards and stopped writing new business. In response, industrial companies founded an insurance cooperative for these risks. For further details, see Radice (2010). 
times of crisis. The literature agrees that in the case of life insurance products with an investment component or a guaranteed annuity, a sudden cancellation of many contracts and a subsequent cash outflow is theoretically possible. The likelihood of such an event, however, is disputed. Radice (2010) and the Geneva Association (2011) argue that policyholders normally have to pay high cancellation fees, making cancellation unattractive.

However, consider the bankruptcy of the Belgian insurance company Ethias in 2008. When the company became financially distressed, many of its life insurance products were cancelled. Nevertheless, the Geneva Association (2010b) argues that the insurance products were in fact saving accounts—-cash could be withdrawn and the contracts cancelled any time without any fee or discount. In addition, Cummins and Weiss (2013) provide further evidence throwing some doubt on the conventional wisdom that cancellations of policies are unlikely. They employed the systemic risk measure SRISK and discovered that it is related to separate account assets and group annuity premiums. Their interpretation is that separate accounts can be associated with increased withdrawals in times of crisis since these accounts are especially used to provide annuities with options and guarantees. Furthermore, large companies are likely to cancel group annuities in times of crisis. Therefore, in line with the discussion of systemic risk measures as mentioned above, it could be argued that life insurance products containing annuities with options or guarantees can indeed increase the vulnerability of an insurer.

Another critical aspect is the rate of return on guaranteed annuities, as pointed out by Radice (2010). If the promised return can be generated only in a bullish market, insurers will suffer financial distress when interest rates plunge and they are not sufficiently hedged. To date, this has happened only to a few insurance companies since the practice of guaranteeing a rate of return on an annuity generally takes several business cycles into account. Even if insurers fail to deliver the guaranteed return, the impact on the economic system is minor. In 
two cases, that of the Japanese insurance company Nissan Mutual Life and Equitable Life in Great Britain, declining interest rates and unhedged, guaranteed annuities caused substantial financial distress for the companies. However, neither case triggered a systemic crisis.

In the non-life segment, the area of credit protection can be divided into three categories: credit insurance, credit guarantees, and derivatives (especially credit default swaps (CDS)). In the case of credit insurance, two industry studies-Baur et al. (2003) and Geneva Association (2010a) — argue that in contrast to CDS underwriting, substantial reserves must be held on the balance sheet for loss events and a cash outflow occurs only in the event of loss when loans can no longer be fully repaid, not in the case of a downgrading. In addition, there is only a weak interconnection between credit insurance and the rest of the financial sector. Thus, the authors conclude that credit insurance's contribution to both systemic risk and vulnerability is low.

Drake and Neale (2011) present a comprehensive study of the financial guarantee business, which underwrites public and private debt as well as structured finance products. The interconnection between this type of business and the financial system is strong due to the exposure of large banks to guaranteed derivatives. In addition, the products react very quickly to market downturns since the securities are valued mark-to-market and losses (or collateral demands) can spread quickly through the financial services industry. Indeed, the Geneva Association (2010a) argues that this business activity significantly increases the issuing insurer's vulnerability to economic downturns. Some products contain implicitly guaranteed interest rates, and rating downgrades of the underwriting entity can trigger immediate collateral calls, as well as contract cancellations. This argument finds support in an empirical study by Chen et al. (2013), which calculates BANKBETA and MES for a broad range of U.S. insurers underwriting CDS. They find that according to both measures, systemic risk levels for financial guarantee insurers exceed those of property-casualty insurers. In 
addition, they evaluate whether the measures can explain the stock market returns of insurers during the financial crisis. Their results show that the explanatory power of both measures in the case of financial guarantee insurers exceeds the one for property-casualty insurers. Therefore, conditional on the appropriateness of these particular systemic risk measures, it can be assumed that financial guarantees increase the contribution to systemic risk as well as the vulnerability of institutions.

The most common credit derivate is the credit default swap. ${ }^{30}$ In its plain-vanilla form, the company selling the swap receives money continuously throughout the duration of the contract and promises to pay out money in the event the entity mentioned in the contract goes bankrupt. To buy a CDS relating to a certain entity, one need not have a claim against the entity itself. ${ }^{31}$ The purchaser of a CDS, however, is exposed to the risk that the counterparty cannot meet its obligation in the event the entity mentioned in the contract goes bankrupt. Therefore, it is common for the CDS seller to provide collateral based on that risk of bankruptcy (see Kress, 2011). Consequently, CDS underwriting businesses are exposed to liquidity risk. They have an increased cash outflow as soon as there is an economic downturn and the risk of credit defaults increases. ${ }^{32}$

We found no disagreement by academics, regulators, or from the industry that CDS underwriting, at the very least, increases vulnerability to impairments of the financial system. When it comes to the contribution to systemic risk, a few studies argue that CDS underwriting has no effect. Wallison (associated with the American Enterprise Institute, a think-tank), as

30 There is controversy over whether CDS qualify as insurance or are, instead, another type of capital market product. See, e.g., NAIC (2000), Schwartz (2007), and Acharya et al. (2011). In the context of this paper, the question is of minor relevance. What matters is that the insurance sector in total underwrites more CDS than it buys for hedging (see Barrett and Ewan, 2006) and in no paper have CDS been considered a form of traditional insurance.

31 Short selling and/or buying uncovered CDS on sovereign debt was forbidden temporarily during the peak of the financial crisis in order to prevent speculation on sovereign debt in many countries. Since then, regulation of the CDS business has become stricter, especially with regard to sovereign debt; see, e.g., regulation of the European Parliament and European Council (2012).

32 CDS can be designed so that there are immediate, realizable losses and not only margin calls. For example, Swiss Re had to realize 1.2 bn CHF in 2007 due to underwriting CDS protecting MBS from rating downgrades (see Swiss Re, 2008). 
reported by Harrington (2009), argues that CDS holding companies are well diversified and, consequently, the insolvency of a CDS underwriting business would have only limited effect. For example, with regard to AIG, he argues that '[i]f Goldman, AIG's largest counterparty, would not have suffered significant losses, there is no reason to believe that anyone else would have suffered systemically significant losses either'. Furthermore, Radice (2010) does not think defaulting CDS would have a huge impact on counterparties. In a qualitative scenario analysis, he, too, argues that the systemic risk contribution of CDS can be easily mitigated by diversifying the counterparties.

In contrast, Heyde and Neyer (2010) build a banking model with and without CDS and compared the results of each with regard to financial stability. They define financial stability as the shock-absorbing ability of the system, that is, the likelihood that a bank goes bankrupt and triggers a chain effect. They find that CDS have a destabilizing effect on the financial system: market participants are not sufficiently diversified and the risk transfers encourage CDS buying banks to invest more in high-profit, but illiquid and risky, assets. This assessment is in line with the majority of academic papers and reports by regulators and the industry agree that the failure of a CDS underwriting entity would trigger a chain reaction that could impair the entire financial system. ${ }^{33}$ This assessment is based on the size of the CDS business, its interconnectedness with the whole financial sector, the short time it takes for an impairment caused by a CDS default to evolve, and the non-transparency of the CDS business. $^{34}$

The U.S. Financial Stability Oversight Council (see FSOC, 2012) provides a different perspective on CDS. It argues that institutions can be systemically relevant also, by being

\footnotetext{
33 Regarding the AIG bailout, Bernanke is reported by Brady (2009) in The Washington Post to have said: 'AIG situation is obviously a very uncomfortable one ... [but a collapse] ... would be devastating to the stability of the world financial system'. See also Acharya et al. (2011).

34 See, e.g., Baluch et al. (2011) and Cummins and Weiss (2014) (peer-reviewed journal articles), IAIS (2011) (regulator report), and Geneva Association (2010a) (industry association report).
} 
reference entities if the notional volume is in excess of \$30 billion. Unfortunately, we found no study that further elaborates this point with regard to insurance companies.

\section{Systemic Risk in Traditional Insurance Funding and Investing Activities}

Traditional funding and investing activities of insurance companies include collecting upfront premiums for underwriting risks and asset and liability management, as well as liquidity management. In addition, insurance-linked securities, specifically, catastrophe bonds, are considered traditional.

In the literature, there is agreement that the business model based on collecting upfront premiums for bearing risks that can lead to contingent claims is a very stable one and ensures sufficient liquidity. Therefore, an 'insurance run' is not possible in the non-life sector and a fire sale of assets that could have a systemic impact is unlikely. ${ }^{35}$ Furthermore, regulators might anticipate the risk of fire sales and automatically relax capital requirements during a crisis (indeed, just such a procedure is expected to be included in the forthcoming Solvency II regulation). ${ }^{36}$ The opposite situation, that is, long-term liabilities and short-term assets, increases insurers' exposure to interest rate risk and their vulnerability as well. However, the Geneva Association (2010a) claims that insurance companies use 'assets and derivatives to replicate insurers' liability profiles and match their expected claims'. This industry view that there should be no maturity mismatch is supported by Cummins and Weiss (2014), who analyse the balance sheets of U.S. non-life and life insurers and conclude that 'asset and liability maturities are both long term for insurers’.

Insurer funding and asset liability management enjoy a certain degree of stability due to the generally high equity coverage in non-life and reinsurance, as reported by Harrington (2009) and Cummins and Weiss (2013). When it comes to life insurers, however, Harrington

\footnotetext{
35 See Geneva Association (2010b) (industry association report), Eling and Schmeiser (2010) (peer-reviewed journal article), Lehmann and Hofmann (2010) (peer-reviewed journal article), and IAIS (2011) (regulator report).

36 See Article 106 in the Directive 2009/138/EC of the European Parliament and European Council (2009).
} 
(2011), Cummins and Weiss (2014), Grace (2011), and Baranoff et al. (2011) argue that the equity basis of life insurers is relatively low. These companies' assets might not be sufficiently diversified (many insurers only hold government bonds), and some companies are substantially invested in mortgage-backed securities. Furthermore, it could be argued that the business model of life insurers in general is more vulnerable to impairment of the financial systems than that of non-life insurers because of contract duration. Life insurance is long-tail business and involves contracts spanning decades. In contrast, non-life insurance is short tail and contracts tend to be short term. Therefore, if loss frequency is low, life insurers have to invest more capital over a longer period of time and are therefore more affected by adverse capital market movements. This indication of life insurers' vulnerability to impairments of the financial system is supported by Chen et al. (2013b), who calculate the systemic risk measures SRISK and MES via a copula approach and discover that life insurers are much more affected by economic downturns than are non-life insurers.

However, a few studies express some doubt that life insurers are vulnerable to impairments of the financial system. Even if an insurance run did materialize, Baranoff et al. (2013) show that the likelihood of a fire sale is small since life insurers maintain a level of liquidity adequate to deal with stressful situations. Simulations based on historical lapse rates show that life insurers need not sell assets before maturity in order fulfil their obligations. Even in a worst-case scenario in which 10 times the normal number of policies is cancelled, the volume of assets that needs to be sold before maturity makes up only a small fraction of the bond market. This line of reasoning is supported by Berry-Stölzle et al. (2014), who show that during the subprime crisis, life insurers' access to external capital was not endangered and TARP funds for life insurers were unnecessary. By using regression analyses, they show that the reasons for issuing new capital—compensating for operational losses or funding growth opportunities - were the same during the subprime crisis as during the normal period 
between 1999 and 2010. In addition, capital issuance can be predicted by the same factors during normal times and times of crisis. No evidence of a shortage of capital for insurers during times of crisis could be found.

There is one aspect of liquidity management that could increase vulnerability in an extremely adverse market environment: fungibility of liquidity in globally operating insurance conglomerates. As Radice (2010) argues, in the event of a crisis, ring-fencing of subsidies by local regulators in an effort to protect local policyholders could lead to an insolvency of the holding company or one of its other subsidiaries, even if the group as a whole continues to be solvent. Drake and Neale (2011), however, stress that guarantees made within different judicial entities in an insurance group could lead to another AIG case: healthy subsidiaries under the oversight of insurance regulators have to pay for the poor decisions of noninsurance, non-regulated entities. ${ }^{37}$

Like the IAIS (2013b), we regard insurance-linked securities (ILS) as a traditional insurance funding and investing activity as long as the underwritten risks are (a) idiosyncratic, (b) not correlated with each other, and (c) not influenced by economic business cycles. The most common ILS are catastrophe bonds and the literature agrees that they are not systemically relevant. Basically, these products use the financial markets to further diversify the underwriting risk of events like pandemics or hurricanes among a wider group of investors. A study by Cummins and Weiss (2009) shows that returns on catastrophe bonds are not correlated with returns on bonds or stocks during normal times and only slightly so in times of crisis. They conclude that cat bonds are valuable for diversification even during crisis. This view is supported in a recent study by Weiß et al. (2013). The authors relate the issuing of cat bonds to systemic risk measures and find that cat bonds have no statistical impact on SRISK or $\Delta$ CoVaR. Finally, Kessler (2013) and IAIS (2011, 2012b) point out that

37 See also the scenario mentioned by the Geneva Association (2012). 
the volume of cat bonds is currently still relatively low and thus cannot be counted as either a contribution to systemic risk or a vulnerability to impairments of the financial system.

Another factor that should prevent contribution to systemic risk by insurers is the high level of market discipline in insurance and reinsurance. Harrington $(2004,2011)$ argues that policyholders are risk sensitive and prefer to deal with financially sound insurers. Furthermore, agents, brokers, and advisors, as well as rating agencies, monitor insurance companies. Therefore, insurance companies limit their risk taking and are careful to maintain a financially healthy position. ${ }^{38}$ Nevertheless, one should not be overconfident that market discipline works in all cases. For example, as Drake and Neale (2011) argue, it was possible for financial guarantee insurers to hide substantial risk exposures in special purpose vehicles outside of the balance sheet.

\section{Systemic Risk in Non-Traditional Insurance Funding and Investing Activities}

We consider the securitization of upfront commission payments, securities lending, and credit rating utilization, as well as short-term funding via issuing commercial papers, as nontraditional funding and investing activities. These activities can be undertaken by life, nonlife, and reinsurance companies.

According to the IAIS (2012b), securitization of upfront commission payments exposes the investor to substantial interest rate risk via implied guarantees, insurance risks, and market risk. However, these business activities do not contribute to systemic risk—at least not yet— since their outstanding volume is marginal compared to other asset-backed securities.

As mentioned above, it is usually not necessary for insurance companies to engage in a fire sale of assets before maturity to overcome liquidity problems. The Geneva Association (2010a) argues that there can be an exception to this if short-term financing is used as the primary form of funding. Two profit-enhancing methods, if used excessively, can increase the

38 Empirical evidence for this reasoning is provided by Epermanis and Harrington (2006). They show for U.S. property-casualty insurers that premium income is decreasing if the insurer's rating is downgraded. More recently, Eling and Schmit (2012) provide evidence of market discipline in the insurance sector for Germany. 
systemic risk contribution of insurers as well as make them more vulnerable to impairments of the financial system:

- 'Securities lending', which is when the insurance company lends its long-term securities to other market participants and therefore receives collateral. The received money is typically invested in short-term assets.

- 'Credit rating utilization', which involves borrowing money as long as the credit rating is not endangered. Again, the additional capital is invested in short-term assets.

Both methods increase the insurance company's liquidity risk and can lead to a situation in which a fire sale of assets becomes necessary in order to meet obligations. When the financial market is already in distress, these particular activities can aggravate the situation, especially if many insurers engage in them. Acharya et al. (2011) point out that securities lending per se need not be a risky activity as long as the collateral is invested in safe assets with a shorter duration than the securities that are borrowed by other institutions. In contrast, AIG engaged in very aggressive securities lending and this was one reason why the company needed financial support. Harrington (2009) makes a similar assessment of the AIG failure, but Baranoff (2012) explains why the securities lending program on its own did not and probably in general will not contribute to systemic risk: market practice normally requires $120 \%$ of the value of the security as cash collateral from the borrower. However, AIG as the lender in the end had to post collateral, too, and so the borrower took no risk. In the event of an AIG bankruptcy, the borrower could have just sold the borrowed securities and the additional collateral. Generally, the right to liquidate the securities in the event of the lender's default limits the counterparty risk and strongly reduces the systemic risk contribution of this business activity. In the case of AIG, the company itself eventually chose to reduce this business activity and turned instead to the Federal Reserve Bank of New York for funding. 
Finally, the Geneva Association (2010a) sheds light on another practice that can contribute to systemic risk and increase vulnerability to impairments of the financial system: relying extensively on short-term funding via issuing commercial papers could lead to the necessity of selling assets before maturity. One should keep in mind, though, that this is a highly unusual practice for standard insurance companies. Effectively, this issue illustrates why one should not focus on the company level, but on the level of business activities. There are systemic risk contributing practices in which insurance companies can engage, but that does not mean that a substantial part of the insurance sector is doing so.

In the reinsurance sector, industry-loss warranties $(I L W)$ can be viewed as non-traditional insurance activities. These warranties are not linked to an individual loss event, but cover the downturn of an entire industry. According to IAIS (2012b), these products can pose an increased basis and credit risk since there is no collateral requirement. With the exception of the case of catastrophe bonds, there are not enough studies on which to base a solid assessment of alternative risk transfer products (ILS and ILW). In addition to ILW, other insurance-linked securities related to life insurance could be strongly connected to interest rate and credit risk as well.

Thus, in principle, all non-traditional funding and investing activities have the potential to increase insurer vulnerability to impairments of the financial system. Whether, and if so, to what extent, these activities contribute to systemic risk is not entirely clear.

\section{Regulation of Systemic Risk in Insurance and Banking}

One major remaining question is whether regulatory requirements designed to mitigate systemic risk should be the same for banking and insurance sectors. Basically, there are three lines of thought on this question.

First, one size fits all. One possibility is to treat insurers exactly the same as banks and to require higher equity levels from insurers that are deemed to be systemically important. This logic is partially followed by the FSB, which states that '[h]igher loss-absorption capacity, 
more intensive supervision and resolution planning requirements will apply to all these institutions [globally systemically important institutions]' (FSB, 2013b).

Second, no systemic risk, no additional regulation. If one argues that insurance does not contribute to systemic risk, then, of course, there should not be any additional regulation. No paper so far argues such an extreme view, but it would be the natural conclusion of the papers finding no systemic risk contribution from non-traditional insurance activities.

Third, market discipline is the key. As discussed above, market discipline is strong in the insurance sector and policyholders, brokers, and agents, as well as other intermediaries, monitor insurance companies. According to this line of thought, well- intended regulatory initiatives can easily have a bad outcome, for example, if regulation becomes more intense, but undermines market discipline. Harrington $(2004,2011)$ is sceptical of additional regulation for systemically important institutions. He argues that a designation as systemically important could be interpreted as a bailout guarantee, which would reduce market discipline.

We believe that all perspectives are valuable as long as they are applied to activities rather than to institutions. We argue in favour of the principle: same business, same risks, same regulation. There is no indication that an improved regulation of AIG's propertycasualty division would have resulted in a less severe financial crisis. At the same time, higher capital requirements would have been a good idea for AIG's financial services division as well as for many banks. Therefore, we approve that an activities-based view has entered the policy debate. ${ }^{39}$ It is important, though, to focus not only on capital requirements but also on transparency. Market discipline can have a beneficial impact only if it is publicly known which business activities are conducted by institutions. In the current discussion, it is sometimes overlooked that it was not only high leverage that was a problem during the crisis, but also the opacity of an institution's risk exposure. Finally, we see no necessity to introduce

\footnotetext{
39 The IAIS (2014) plans to differentiate between traditional and non-traditional activities in their formula for basic capital requirements.
} 
additional systemic-risk-oriented regulation of traditional insurance activities, since they do not contribute to systemic risk.

\section{Conclusions and Directions for Future Research}

In this paper we discuss, and review the extant literature on, systemic risk, a topic of high interest for academics and practitioners in the last few years. Systemic risk can occur when there is a limited shock that spreads via contagion or interdependence to other financial institutions or upon the occurrence of a system-wide shock that impacts the entire financial system at once.

There is agreement in the literature that insurance companies and their activities contribute less to systemic risk and are less vulnerable to impairments of the financial system than are banks. Traditional underwriting and funding and investing activities in the life, nonlife, and reinsurance business contribute very little to systemic risk and do not increase insurer vulnerability to impairments of the financial system. However, certain non-traditional insurance activities do appear to be relevant to systemic risk. The literature agrees that some underwriting activities in the life segment (annuities with guarantees) and in the non-life segment (financial guarantees and CDS) increase insurers' vulnerability to impairments of the financial system. A majority of academic studies, working papers, regulator reports, and industry studies claim that these activities also contribute to systemic risk; only a minority argues that these products make a very limited contribution to systemic risk.

According to the literature, in principle, traditional funding and investing activities (including catastrophe bonds) neither contribute to systemic risk nor increase the vulnerability of an institution in times of crisis. With regard to non-traditional funding and investing activities, it is securities lending, short-term funding, and industry-loss warranties that can especially increase vulnerability to impairments of the financial system. However, no consensus has yet been reached as to whether and, if so, to what extent these activities 
contribute to systemic risk. Furthermore, there is to date very little work on alternative risk transfer products.

Studies taking a qualitative approach to the issue and studies that calculate systemic risk measures conclude that life insurance companies are more vulnerable to impairments of the financial system than are non-life insurers. Our review of 30 academic and 13 industry papers reveals that, in general, both groups agree when it comes to systemic risk.

A final contribution of this paper is that we systematically searched the extant literature for open research questions on the topic of systemic risk and, as Table 4 shows, discovered that there is a lot of room for future research. In Table 4, we also include some of our own suggestions for future research on this topic.

\begin{tabular}{|c|c|c|}
\hline Main Issue & Paper & Open Research Questions \\
\hline \multirow[t]{10}{*}{ Regulation } & Vaughan (2009) & $\begin{array}{l}\text { - What is the appropriate trade-off in insurance regulation between 'checks and } \\
\text { balances' and unnecessary high costs? }\end{array}$ \\
\hline & Acharya et al. (2011) & $\begin{array}{l}\text { - CDS are essentially insurance. Is some form of insurance regulation needed for such } \\
\text { products? }\end{array}$ \\
\hline & Weiß and Mühlnickel (2013) & $\begin{array}{l}\text { - What is the impact of divestitures of large insurers on systemic risk in the insurance } \\
\text { industry? }\end{array}$ \\
\hline & Based on Al-Darwish et al. & - How is systemic risk considered in insurance regulation? \\
\hline & (2011), Ashby (2011), Keller & - Do the current regulation frameworks mitigate or contribute to systemic risk? \\
\hline & (2011), and Haldane (2012) & $\begin{array}{l}\text { - Is regulation arbitrage possible between the banking and the insurance sector? } \\
\text { - Will the probably higher future capital requirements in the banking and insurance } \\
\text { sectors transfer risk to consumers or other market participants? }\end{array}$ \\
\hline & Weiß and Mühlnickel (2013) & - Can differences in global insurance regulation affect an insurer's systemic relevance? \\
\hline & Further questions & $\begin{array}{l}\text { - Does the identification of global systemically important insurers lead to an implied } \\
\text { bailout guarantee and moral hazard? }\end{array}$ \\
\hline & & - How can regulation be designed so that it is not procyclical? \\
\hline & & $\begin{array}{l}\text { - Banking versus insurance: which regulation leads to stricter capital requirements and } \\
\text { does this open the door for regulatory arbitrage? }\end{array}$ \\
\hline \multirow{6}{*}{$\begin{array}{l}\text { Traditional } \\
\text { Business } \\
\text { Activities }\end{array}$} & Park and Xie (2014) & $\begin{array}{l}\text { - How do insurance companies react when both insurers and reinsurers simultaneously } \\
\text { experience a macroeconomic shock? }\end{array}$ \\
\hline & & - What is the impact of a reinsurer's insolvency on affiliated insurance companies? \\
\hline & Van Lelyveld et al. (2011) & $\begin{array}{l}\text { - Could primary insurers be influenced by a reinsurer default in a way other than via } \\
\text { credit risks (e.g., reputational risks)? } \\
\text { - What is the effect of reinsurer insolvencies if primary insurers are already impaired? }\end{array}$ \\
\hline & Chen et al. (2013a) & $\begin{array}{l}\text { - Banks contribute to systemic risk. What are the mechanisms through which banking } \\
\text { shocks are transmitted to the insurance industry? }\end{array}$ \\
\hline & Baluch et al. (2011) & - The banking and insurance sectors are interconnected, but how and to what extent? \\
\hline & Further questions & $\begin{array}{l}\text { - How can contagion effects be measured? Are positive correlations in prices sufficient } \\
\text { to imply contagion risks? }\end{array}$ \\
\hline \multirow{7}{*}{$\begin{array}{l}\text { Non- } \\
\text { Traditional } \\
\text { Business } \\
\text { Activities }\end{array}$} & Harrington (2009) & - Did AIG’s CDS portfolios contribute to systemic risk due to contagion? \\
\hline & Cummins and Weiss (2014) & $\begin{array}{l}\text { - More research is needed about 'non-core activities of insurers' and their systemic } \\
\text { impact. }\end{array}$ \\
\hline & IAIS (2012b) & $\begin{array}{l}\text { - Do non-traditional insurance activities related to the financial markets (e.g., CDS, } \\
\text { industry-loss warranties) empirically amplify or contribute to systemic risk? }\end{array}$ \\
\hline & Cummins and Weiss (2013) & $\begin{array}{l}\text { - Some studies show increased interconnectedness between banks and insurers. Also, } \\
\text { some systemic risk measures are high for insurance companies. Are core or non-core } \\
\text { activities causing these results or is it some other characteristic of the insurers? }\end{array}$ \\
\hline & Further questions & $\begin{array}{l}\text { - Which of the current systemic risk measures are adequate to measure an insurer's } \\
\text { contribution to systemic risk? }\end{array}$ \\
\hline & & $\begin{array}{l}\text { - Which of the current systemic risk measures are adequate to measure an insurer's } \\
\text { vulnerability to impairments of the financial system? }\end{array}$ \\
\hline & & - Do alternative risk transfer products contribute to systemic risk? \\
\hline
\end{tabular}

Table 4: Open research questions 
Open research questions can be sorted into three types: (1) regulation, (2) traditional business activities, and (3) non-traditional business activities.

With regard to regulation, the major research question that remains to be answered is how regulation can be designed so that systemic risk is mitigated. This issue is currently under discussion and no consensus has yet been reached. Also, a question that is not thoroughly considered in the literature is whether new regulation (e.g., Solvency II) might contribute to systemic risk, as is sometimes discussed in academia and practice (see, e.g., Eling et al., 2008). In particular, the IMF (2007) argues that regulatory convergence can decrease the variety of applied risk models and discourage contrarian behaviour in times of crisis. Consequently, regulatory regimes might destabilize the financial system. Furthermore, how to prevent regulation arbitrage is still an open question.

With respect to traditional insurance activities, studies find that the stock market prices of insurance companies and other companies in the financial services industry are correlated. Nevertheless, more research into the specifics of this interconnection is necessary. To date, it is mainly measured by Granger-causality tests, linear correlation, and principal components analysis. Furthermore, even if, in general, there is agreement in the literature that the potential for systemic risk is very low in traditional insurance activities, indirect contagion effects, such as reputational risks, have not yet been analysed. Also, all studies on reinsurance risk find that traditional reinsurance activities neither contribute to systemic risk nor increase vulnerability, but all this work focuses on single facets of the reinsurance sector. A more comprehensive approach that takes into account several types of interconnection, as well as 'second-round' effects, would be useful.

With respect to non-traditional insurance activities, a controversial topic that has room for more research is the systemic risk contribution of derivatives and other innovative products from the field of alternative risk transfer, especially insurance-linked securities and industryloss warranties. Furthermore, studies that link the results of systemic risk measures to characteristics of insurance companies would definitely profit from more discussion of these 
measures and preconditions for their application. The link between the measures and the actual systemic risk definitions is not clear. In the literature, there is still no common understanding of systemic risk and, consequently, systemic risk measures often arrive at contradictory conclusions. In this paper we argue that the starting point should be the financial crisis and we provide a framework for how to think about a systemic risk definition. Our argument is that the whole systemic risk discussion is based on the goal of preventing such a crisis from ever occurring again. Therefore, it would be helpful if the scientific community could agree on a definition of the risks that led to this disaster. We believe that accomplishing this first step would be of enormous benefit in the next step of designing an appropriate systemic risk measure. Currently, as shown in the discussion above, too many issues regarding these measures remain. For example, in which cases is the application of a systemic risk measure appropriate? Is it sufficient to rely on stock price information to measure an interconnection? Is a macro-prudential systemic risk measure necessary, one that would indicate, for example, when the overall systemic risk level in the financial system is high? How can the quality of systemic risk measures be assessed? In our opinion, the vast number of measures and the fact that a certain measure is sometimes used for measuring systemic risk contribution and sometimes for measuring vulnerability indicates that more research in this area is needed. 


\section{Appendix}

\begin{tabular}{|c|c|}
\hline Reference & Definition \\
\hline $\begin{array}{l}\text { Acharya et al. } \\
\text { (2011, p. 281) }\end{array}$ & $\begin{array}{l}\text { 'Systemic risk can be conceived as the potential failure of a significant part of the financial sector-one large } \\
\text { institution or many smaller ones-leading to reductions in the availability of credit and/or critical risk management } \\
\text { products such as insurance, thereby adversely affecting the real economy'. }\end{array}$ \\
\hline $\begin{array}{l}\text { Adrian and } \\
\text { Brunnermeier } \\
\text { (2011, p. 1) }\end{array}$ & $\begin{array}{l}\text { 'The spreading of distress gives rise to systemic risk-the risk that the intermediation capacity of the entire financial } \\
\text { system is impaired, with potentially adverse consequences for the supply of credit to the real economy'. } \\
\text { '.. }\end{array}$ \\
\hline $\begin{array}{l}\text { Adrian and } \\
\text { Brunnermeier } \\
\text { (2011, p. 1), based } \\
\text { on Brunnermeier et } \\
\text { al. (2009) }\end{array}$ & $\begin{array}{l}\text { 'A systemic risk measure should identify the risk on the system by individually systemic institutions, which are so } \\
\text { interconnected and large that they can cause negative risk spillover effects on others, as well as by institutions which } \\
\text { are systemic as part of a herd'. }\end{array}$ \\
\hline $\begin{array}{l}\text { Baur et al. } \\
(2003, \text { p. } 7)\end{array}$ & $\begin{array}{l}\text { 'Systemic risk is the danger that an event will trigger a loss of economic value and/or confidence in the financial } \\
\text { system that has significant adverse effects on the real economy'. }\end{array}$ \\
\hline $\begin{array}{l}\text { Bach and } \\
\text { Nguyen (2012, p. } \\
\text { 131) }\end{array}$ & $\begin{array}{l}\text { 'Hence, macroprudential regulation focuses on systemic risk-it refers to the risk of a malfunction of the financial } \\
\text { system to an extent big enough to affect economic growth and welfare ...' }\end{array}$ \\
\hline $\begin{array}{l}\text { Baluch et al. } \\
\text { (2011, p. 137) }\end{array}$ & $\begin{array}{l}\text { "However, the term "systemic risk" is somewhat ambiguous with regard to both its definition and derivation. A widely } \\
\text { accepted definition of systemic risk is that of Csiszar who characterise it as "the risk that the failure of a participant to } \\
\text { meet its contractual obligations may in turn cause other participants to default, with the chain reaction leading to } \\
\text { broader financial difficulties". However, this definition includes only the sort of "micro" systemic risk represented by } \\
\text { a cumulative loss function caused by a domino effect .... }\end{array}$ \\
\hline $\begin{array}{l}\text { Bernanke as } \\
\text { reported by Boles } \\
\text { (2009) }\end{array}$ & $\begin{array}{l}\text { 'Systemic risks are developments that threaten the stability of the financial system as a whole and consequently the } \\
\text { broader economy, not just that of one of two institutions'. }\end{array}$ \\
\hline $\begin{array}{l}\text { Billio et al. } \\
\text { (2010, p. 1) }\end{array}$ & $\begin{array}{l}\text { 'Systemic risk can be defined as the probability that a series of correlated defaults among financial institutions, } \\
\text { occurring over a short time span, will trigger a withdrawal of liquidity and widespread loss of confidence in the } \\
\text { financial system as a whole'. }\end{array}$ \\
\hline $\begin{array}{l}\text { Billio et al. } \\
\text { (2012, p. 536) }\end{array}$ & $\begin{array}{l}\text { 'By definition, systemic risk involves the financial system, a collection of interconnected institutions that have } \\
\text { mutually beneficial business relationships through which illiquidity, insolvency, and losses can quickly propagate } \\
\text { during periods of financial distress'. }\end{array}$ \\
\hline $\begin{array}{l}\text { Chen et al. } \\
\text { (2013a, p. 1) }\end{array}$ & $\begin{array}{l}\text { 'From a statistical perspective, systemic risk involves the co-movement of key financial variables measuring the } \\
\text { health of stability of financial institutions and has also been described as the potential for multiple simultaneous } \\
\text { defaults of major financial institutions'. }\end{array}$ \\
\hline $\begin{array}{l}\text { Chen et al. } \\
\text { (2013b, p. 1) }\end{array}$ & $\begin{array}{l}\text { 'Systemic risk can be defined as the risk that an event will generate a loss of economic value or confidence in a } \\
\text { substantial segment of the financial system, which in turn could also affect the entire economy'. }\end{array}$ \\
\hline Csiszar (2002, p. 2) & $\begin{array}{l}\text { 'What is Systemic Risk? The risk that the failure of a participant to meet its contractual obligations may in turn cause } \\
\text { other participants to default, with the chain reaction leading to broader financial difficulties'. }\end{array}$ \\
\hline $\begin{array}{l}\text { Committee on } \\
\text { Capital Markets } \\
\text { Regulation } \\
\text { (CCMR) (2009, p. } \\
\text { ES-3) }\end{array}$ & $\begin{array}{l}\text { 'Systemic risk is the risk of collapse of an entire system or entire market, exacerbated by links and interdependencies, } \\
\text { where the failure of a single entity or cluster of entities can cause a cascading failure. We recognize that there are at } \\
\text { least five key externalities particular to financial markets that contribute to systemic risk. First, the spread of } \\
\text { speculative information through the market can create the perception that economic difficulties impacting one } \\
\text { financial institution will affect similarly situated firms. Second, customers of failed institutions may subsequently find } \\
\text { themselves in a less friendly market when looking to re-direct their business. Third, there is considerable inter- } \\
\text { connectedness between the financial institutions participating in modern financial markets, so that the failure of one } \\
\text { firm can affect many others. Fourth, a negative spiral may be created by falling asset prices and resulting liquidity } \\
\text { constrictions. Fifth, falling asset prices and liquidity crises could cause institutions to become reluctant to extend } \\
\text { credit'. }\end{array}$ \\
\hline $\begin{array}{l}\text { Cummins and } \\
\text { Weiss (2014, p. 2) }\end{array}$ & $\begin{array}{l}\text { 'Systemic risk is the risk that an event will trigger a loss of economic value or confidence in a substantial segment of } \\
\text { the financial system that is serious enough to have significant adverse effects on the real economy with a high } \\
\text { probability'. }\end{array}$ \\
\hline $\begin{array}{l}\text { De Bandt and } \\
\text { Hartmann }(2000, p . \\
\text { 11) }\end{array}$ & $\begin{array}{l}\text { 'Systemic risk (in the narrow and broad sense) can then be defined as the risk of experiencing systemic events in the } \\
\text { strong sense'. See also page } 10 \text { for an understanding of the context. }\end{array}$ \\
\hline Grace (2011, p. 2) & $\begin{array}{l}\text { 'First, "Systemic risk refers to the } \ldots \text { breakdown in an entire system. ... This ... risk ... is evidenced by a high } \\
\text { correlation and clustering of ... failures." A second definition concerns contagion. One failure by an institution leads } \\
\text { to a failure of another. This chain reaction requires linkages among firms, markets or sectors. Finally, a third } \\
\text { definition focuses on an externality caused by a shock to one firm which creates uncertainty about other firms. For } \\
\text { example, a firm suffers a loss and the market then becomes uncertain about the value of similar firms'. }\end{array}$ \\
\hline $\begin{array}{l}\text { Group of Ten } \\
\text { (2001, p. 126) }\end{array}$ & $\begin{array}{l}\text { 'Systemic financial risk is the risk that an event will trigger a loss of economic value or confidence in, and attendant } \\
\text { increases in uncertainly about, a substantial portion of the financial system that is serious enough to quite probably } \\
\text { have significant adverse effects on the real economy'. }\end{array}$ \\
\hline $\begin{array}{l}\text { Harrington } \\
\text { (2009, p. 801) }\end{array}$ & $\begin{array}{l}\text { "There is no generally accepted definition of "systemic risk" or agreement on its importance and scope. While the } \\
\text { term sometimes is used to encompass the risk of any large, macroeconomic shock, the term generally is used to } \\
\text { connote situations with extensive interdependencies or "interconnectedness" among firms and an associated risk of } \\
\text { contagion and significant economic spillovers'. }\end{array}$ \\
\hline $\begin{array}{l}\text { Harrington } \\
(2011, \text { p. 4) }\end{array}$ & $\begin{array}{l}\text { "The term "systemic risk" generally is used broadly to encompass the risk of any large, macroeconomic shock and the } \\
\text { risk arising from extensive interdependencies or "interconnectedness" among firms, with an attendant risk of } \\
\text { contagion and significant economic spillovers. There is a distinction, however, between the risk of common shocks to } \\
\text { the economy, such as widespread reductions in housing prices or large changes in interest rates or foreign exchange, }\end{array}$ \\
\hline
\end{tabular}




\begin{tabular}{|c|c|}
\hline & $\begin{array}{l}\text { hich have the potential to directly harm large numbers of people and firms, and financial risk that arises from } \\
\text { terconnectedness and contagion'. }\end{array}$ \\
\hline $\begin{array}{l}\text { Huang et al. } \\
\text { (2009, p. 2036) }\end{array}$ & $\begin{array}{l}\text { 'First, how to measure the systemic risk of a financial system, where systemic risk is defined as multiple simultaneous } \\
\text { defaults of large financial institutions?' }\end{array}$ \\
\hline IAIS (2009, p. 1) & $\begin{array}{l}\text { 'The risk of disruption to the flow of financial services that is (i) caused by an impairment of all or parts of the } \\
\text { financial system; and (ii) has the potential to have serious negative consequences for the real economy'. }\end{array}$ \\
\hline Jobst (2012, p. 3) & $\begin{array}{l}\text { 'Systemic risk refers to individual or collective financial arrangements-both institutional and market-based-that } \\
\text { could either lead directly to system-wide distress in the financial sector and/or significantly amplify its consequences } \\
\text { (with adverse effects on other sectors, in particular capital formation in the real economy). The potential emergence of } \\
\text { systemic risk and its impact on financial stability is significantly influenced by institutions whose disorderly failure, } \\
\text { because of their size, complexity and systemic interconnectedness, would cause significant disruption to the financial } \\
\text { system and economic activity ...' }\end{array}$ \\
\hline $\begin{array}{l}\text { Kaufmann and } \\
\text { Scott (2003, p. } \\
\text { 372) }\end{array}$ & $\begin{array}{l}\text { 'A search of the literature reveals three frequently used concepts. The first refers to a "big" shock or macroshock that } \\
\text { produces nearly simultaneous, large, adverse effects on most or all of the domestic economy or system. Here, } \\
\text { systemic "refers to an event having effects on the entire banking, financial, or economic system, rather than just one } \\
\text { or a few institutions"...' } \\
\text { '. The other two definitions focus more on the microlevel and on the transmission of the shock and potential spillover } \\
\text { form one unit to others'. }\end{array}$ \\
\hline Klein (2011, p. 5) & $\begin{array}{l}\text { 'Systemic risk could be defined as the risk that a market or financial system could experience severe instability, } \\
\text { potentially catastrophic, caused by idiosyncratic events or conditions in financial intermediaries. It arises from the } \\
\text { links between firms in a system or market where the failure of one or more firms can have cascading effects which } \\
\text { could potentially bring down an entire system or market. This is a kind of market failure that can arise from excessive } \\
\text { risk taking by financial institutions whose failure can lead to the failure of other firms in a market or system'. }\end{array}$ \\
\hline $\begin{array}{l}\text { Kress } \\
(2011, \text { p. 57) }\end{array}$ & $\begin{array}{l}\text { 'The aggregation of CDS counterparty risk throughout financial markets creates systemic risk, the possibility of } \\
\text { contagion spreading from institution to institution'. }\end{array}$ \\
\hline $\begin{array}{l}\text { Rodriguez-Moreno } \\
\text { and Peña } \\
(2013 \text {, p. 1) }\end{array}$ & $\begin{array}{l}\text { 'Systemic risk appears when generalized malfunctioning in the financial system threatens economic growth and } \\
\text { welfare. The causes of this malfunction are multiple and therefore a single measure of systemic risk may neither be } \\
\text { appropriate nor desirable'. }\end{array}$ \\
\hline
\end{tabular}

Table A1: Definitions of systemic risk in the literature 


\section{Types of Impairments}

There are two ways impairments can take place-a system-wide shock or a limited shock with subsequent contagion.

- A system-wide shock is one external shock that has a direct negative impact on most or all financial services companies; as a consequence, these institutions can no longer offer their full range of services. Like De Bandt and Hartmann (2000), we also understand that new information can be a shock of this type. For example, suppose a certain regulatory requirement suddenly encourages financial institutions to sell a certain asset. As a consequence, most institutions start to sell this asset, the price of the asset decreases, and the institutions become distressed because the remaining assets of this type that they still hold have lost value. In this way, the institutions' aligned behaviour caused by the new information impairs the financial system.

- A limited shock with subsequent contagion occurs when one or a few market participants cannot meet their obligations, e.g., for internal reasons or due to an external shock. This shock spreads in a chain reaction across the entire financial system. Contagion can take different forms:

o bankruptcies of institutions, which trigger insolvencies of other companies due to unfulfilled commitments,

o contracts based on credit ratings,

o decrease in asset prices caused by sales by a few institutions that force other market participants to sell assets as well,

o investor uncertainty, eventually resulting in aligned behaviour, due to the distress of one company combined with non-transparency as to whether other companies are experiencing the same problem, ${ }^{40}$

\footnotetext{
40 See Harrington (2009) and Cummins et al. (2012).
} 
o information, eventually resulting in aligned behaviour, about the distress of one company from which markets conclude that other companies face similar problems, and

0 irrationality. $^{41}$

Some definitions of contagion differentiate between the state of the economy at the time the contagion occurs (normal vs. extreme economic conditions) and between whether the shock is based on rational or irrational reasons (see Figure A1). ${ }^{42}$ In this paper, we define contagion as 'a significant increase in linkages between financial institutions after a shock to one institution (or a group of institutions)'. ${ }^{43}$ Therefore, we differentiate only between the conditions in which interdependence and contagion (including spillover effects) occurs (i.e., normal vs. extreme); we do not differentiate between how a shock is transmitted (rationally vs. irrationally).

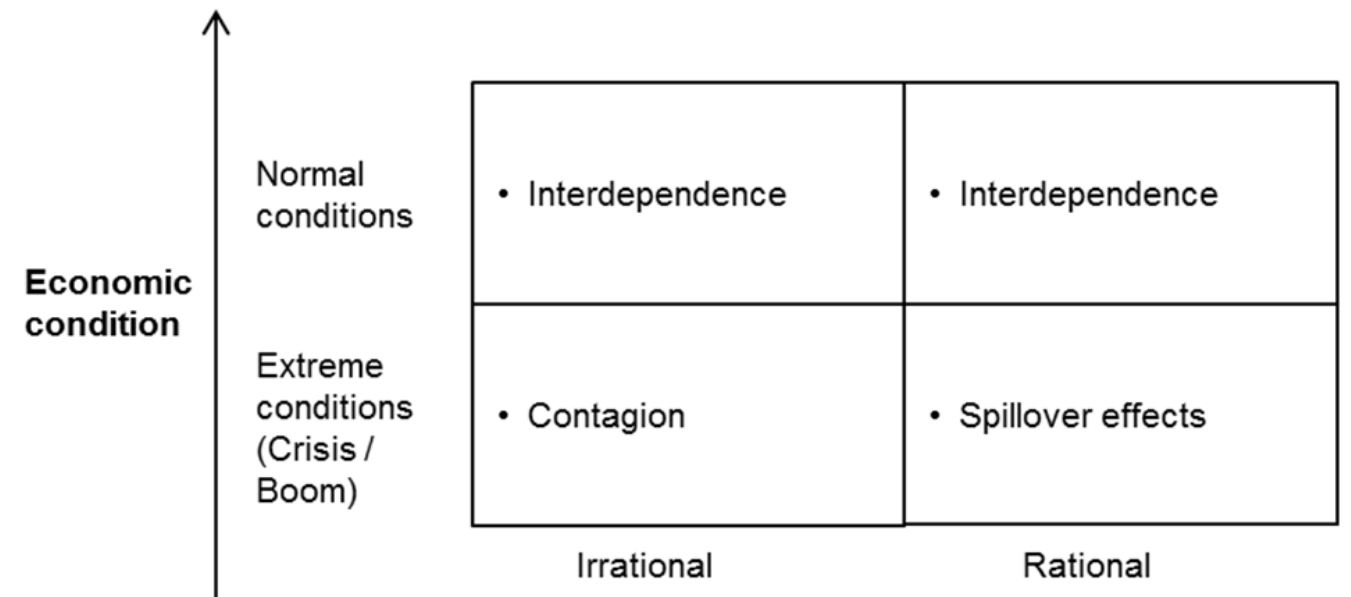

Market behaviour

Figure A1: Classification of different shock transmission mechanisms

41 See Harrington (2009, 2011) and Park and Xie (2014, p. 30).

42 For an overview of different perceptions of contagion, see Forbes (2012).

43 This definition of contagion, interdependence, and spillover effects is based on Forbes and Rigobon (2002). 


\begin{tabular}{|c|c|c|c|c|c|c|}
\hline \multicolumn{7}{|c|}{ Part A: Academic Papers } \\
\hline No. & Author & Year & \begin{tabular}{|l|} 
Title/ \\
Published in \\
\end{tabular} & \begin{tabular}{|l|} 
Focus and \\
Methodology
\end{tabular} & Research Question & Main Result \\
\hline 1 & $\begin{array}{l}\text { Jean-Claude } \\
\text { Trichet }\end{array}$ & 2005 & \begin{tabular}{|l|} 
Financial Stability \\
and the Insurance \\
Sector \\
\\
The Geneva \\
Papers on Risk \\
and Insurance-- \\
Issues and Practice
\end{tabular} & $\begin{array}{l}\text { - Financial stability } \\
\text { - Life, non-life } \\
\text { - Qualitative } \\
\text { discussion } \\
\end{array}$ & $\begin{array}{l}\text { - Which risks does } \\
\text { the insurance } \\
\text { industry pose to } \\
\text { financial } \\
\text { stability? }\end{array}$ & $\begin{array}{l}\text { - Due to maturity transformation and fast } \\
\text { transmission mechanisms, banks contribute to } \\
\text { systemic risk } \\
\text { - Traditional insurance business is not } \\
\text { vulnerable to ‘insurance runs' and } \\
\text { interconnectedness in comparison to banks is } \\
\text { low, so traditional insurance does not } \\
\text { contribute to systemic risk } \\
\text { - New business activities of insurers can lead to } \\
\text { contagion affecting banks: } \\
\text { - Selling of credit risk transfer instruments } \\
\text { (derivatives); banks are net buyers and } \\
\text { insurers net sellers } \\
\text { - Bancassurance (banking groups engage in } \\
\text { insurance); regulatory arbitrage might be } \\
\text { possible } \\
\text { - Participation of insurers in financial } \\
\text { markets; fire sales might trigger a downward } \\
\text { spiral }\end{array}$ \\
\hline 2 & \begin{tabular}{|l|} 
Scott E. \\
Harrington
\end{tabular} & 2009 & $\begin{array}{l}\text { The Financial } \\
\text { Crisis, Systemic } \\
\text { Risk, and the } \\
\text { Future of } \\
\text { Insurance } \\
\text { Regulation } \\
/ \\
\text { Journal of Risk } \\
\text { and Insurance }\end{array}$ & $\begin{array}{l}\text { - AIG case } \\
\text { - Life, non-life } \\
\text { - Qualitative } \\
\text { discussion based } \\
\text { on descriptive } \\
\text { statistics }\end{array}$ & $\begin{array}{l}\text { - Discussion of the } \\
\text { AIG case } \\
\text { - Does insurance } \\
\text { contributes to } \\
\text { systemic risk? } \\
\text { - How should } \\
\text { regulation be } \\
\text { drafted? }\end{array}$ & $\begin{array}{l}\text { - AIG became distressed because of its } \\
\text { derivative writing business and securities } \\
\text { lending program } \\
\text { - It is unclear if financial support was necessary; } \\
\text { insurance subsidiaries would probably have } \\
\text { avoided bankruptcy } \\
\text { - Traditional insurance products do not } \\
\text { contribute to systemic risk } \\
\text { - Market transparency should be increased, but } \\
\text { there should be no too-big-to-fail regulation } \\
\text { for insurers }\end{array}$ \\
\hline 3 & $\begin{array}{l}\text { Marc P. } \\
\text { Radice }\end{array}$ & $\begin{array}{l}2010 \\
\text { (June) }\end{array}$ & $\begin{array}{l}\text { Systemische } \\
\text { Risiken im } \\
\text { Versicherungs- } \\
\text { sektor? } \\
\text { / } \\
\text { Working Paper }\end{array}$ & $\begin{array}{l}\text { - Systemic risk } \\
\text { - Life, non-life } \\
\text { - Scenario analysis } \\
\text { based on } \\
\text { qualitative } \\
\text { assessments of the } \\
\text { insurance industry }\end{array}$ & $\begin{array}{l}\text { - Can systemic risk } \\
\text { be found within } \\
\text { the insurance } \\
\text { sector? } \\
\end{array}$ & \begin{tabular}{|l|} 
- Following scenarios do not identify \\
contributions to systemic risk: \\
- Unavailability of insurance, \\
- Insurance run on life insurers, \\
- CDS payment default, \\
- Credit rating utilization (long-term \\
investment, short-term funded) \\
- Following scenarios could be systemically \\
risky: \\
- Asset contagion, \\
- Limited fungibility of available group \\
- liquidity, \\
- Distress of non-regulated/non-insurance \\
business within an insurance group \\
\end{tabular} \\
\hline 4 & \begin{tabular}{|l|} 
Viral V. \\
Acharya, \\
John Biggs, \\
Hanh Le, \\
Matthew \\
Richardson, \\
Stephen Ryan \\
\end{tabular} & 2011 & \begin{tabular}{|l|} 
Systemic Risk and \\
the Regulation of \\
Insurance \\
Companies \\
$/$ \\
Regulating Wall \\
Street-The \\
Dodd-Frank Act \\
and the New \\
Architecture of \\
Global Finance \\
\end{tabular} & $\begin{array}{l}\text { - Regulation } \\
\text { - Life, non-life, } \\
\text { reinsurance } \\
\text { - Qualitative } \\
\text { discussion based } \\
\text { on descriptive } \\
\text { statistics and } \\
\text { systemic risk } \\
\text { measure } \\
\text { calculation }\end{array}$ & $\begin{array}{l}\text { How to shape } \\
\text { regulation and } \\
\text { treat systemically } \\
\text { risky institutions? }\end{array}$ & $\begin{array}{l}\text { - MES is calculated for U.S. insurance } \\
\text { companies at July } 2007 \\
\text { - Insurers with a traditional business model pose } \\
\text { low systemic risk in contrast to companies } \\
\text { engaged in non-traditional insurance products } \\
\text { - A federal regulator is proposed who manages } \\
\text { ex ante and ex post the systemic risk of large } \\
\text { insurers } \\
\text { - Institutions that are too interconnected to fail } \\
\text { should pay a fee for the implicit guarantee of } \\
\text { being bailed out in the case of crisis } \\
\text { - Insurance products relating to systemic risks } \\
\text { (e.g., insolvency of AAA-CDOs or a nuclear } \\
\text { attack) should be forbidden unless fully } \\
\text { capitalized }\end{array}$ \\
\hline 5 & $\begin{array}{l}\text { Faisal Baluch, } \\
\text { Stanley } \\
\text { Mutenga, } \\
\text { Chris Parsons }\end{array}$ & 2011 & \begin{tabular}{|l|} 
Insurance, \\
Systemic Risk and \\
the Financial \\
Crisis \\
$/$ \\
The Geneva \\
Papers on Risk \\
and Insurance-- \\
Issues and Practice
\end{tabular} & $\begin{array}{l}\text { - Systemic risk } \\
\text { - Life, non-life, } \\
\text { reinsurance } \\
\text { - Qualitative } \\
\text { discussion based } \\
\text { on descriptive } \\
\text { statistics and } \\
\text { correlation } \\
\text { analysis }\end{array}$ & $\begin{array}{l}\text { - What was the role } \\
\text { of the insurance } \\
\text { industry during } \\
\text { the financial } \\
\text { crisis? }\end{array}$ & $\begin{array}{l}\text { - The impact of the financial crisis on the } \\
\text { insurance industry was less severe than on the } \\
\text { banking industry } \\
\text { - Companies with insurance and banking } \\
\text { businesses suffered especially } \\
\text { - Systemic risk in insurance has grown in the } \\
\text { last years, since insurers increased their } \\
\text { participation in the capital markets and offered } \\
\text { more banking services }\end{array}$ \\
\hline
\end{tabular}




\begin{tabular}{|c|c|c|c|c|c|c|}
\hline 6 & $\begin{array}{l}\text { Dwityapoetra } \\
\text { Besar, Philip } \\
\text { Booth, Ka K. } \\
\text { Chan, Alastair } \\
\text { K. L. Milne, J. } \\
\text { Pickles }\end{array}$ & 2011 & \begin{tabular}{|l|} 
Systemic Risk in \\
Financial Services \\
$/$ \\
British Actuarial \\
Journal
\end{tabular} & $\begin{array}{l}\text { - Systemic risk } \\
\text { - Life, non-life, } \\
\text { reinsurance } \\
\text { - Qualitative } \\
\text { discussion and } \\
\text { four case studies } \\
\text { based on } \\
\text { qualitative } \\
\text { assessments of } \\
\text { financial crisis }\end{array}$ & $\begin{array}{l}\text { - What is systemic } \\
\text { risk? } \\
\text { - Where does } \\
\text { systemic risk } \\
\text { originate in the } \\
\text { financial system? }\end{array}$ & $\begin{array}{l}\text { - Systemic risk can originate in four 'networks } \\
\text { of interconnections' between financial } \\
\text { institutions: } \\
\text { - Payment systems, financial infrastructure, } \\
\text { systems of clearing and settlement } \\
\text { - Short-term funding markets } \\
\text { - Common exposure of several institutions in } \\
\text { collateral, securities, and derivatives market } \\
\text { - Counterparty exposure } \\
\text { - Insurers do not contribute to systemic risk, } \\
\text { since insurers are only affected by the last } \\
\text { issue and, in the case of life insurers and } \\
\text { pension funds, by the third issue as well; } \\
\text { however, in a much more limited way than } \\
\text { banks }\end{array}$ \\
\hline 7 & $\begin{array}{l}\text { Iman van } \\
\text { Lelyveld, } \\
\text { Franka } \\
\text { Liedorp, } \\
\text { Manuel } \\
\text { Kampman }\end{array}$ & 2011 & \begin{tabular}{|l|} 
An Empirical \\
Assessment of \\
Reinsurance Risk \\
$/$ \\
Journal of \\
Financial Stability
\end{tabular} & $\begin{array}{l}\text { - Contagion } \\
\text { - Reinsurance } \\
\text { - Scenario analysis } \\
\text { based on a matrix } \\
\text { showing the } \\
\text { reinsurance } \\
\text { linkages between } \\
\text { insurers-insurers } \\
\text { and insurers- } \\
\text { reinsurers }\end{array}$ & $\begin{array}{l}\text { - Do linkages } \\
\text { between } \\
\text { reinsurers and } \\
\text { insurers } \\
\text { contribute to } \\
\text { systemic risk via } \\
\text { a threat of } \\
\text { contagion? }\end{array}$ & $\begin{array}{l}\text { - } 213 \text { Dutch insurers and their reinsurance } \\
\text { exposure are analysed as of } 2005 \\
\text { - Scenario analysis shows that } \\
\text { - Potential failure of any one reinsurer is not a } \\
\text { systemic risk } \\
\text { - Potential failure of reinsurers from a } \\
\text { particular geographic region is not a } \\
\text { systemic risk } \\
\text { - Potential failure of the two largest reinsurers } \\
\text { in the life and non-life segment is not a } \\
\text { systemic risk } \\
\text { - Even if many reinsurers went bankrupt, the } \\
\text { market would not fail and only a few primary } \\
\text { insurers would go bankrupt }\end{array}$ \\
\hline 8 & $\begin{array}{l}\text { Martin F. } \\
\text { Grace }\end{array}$ & $\begin{array}{l}2011 \\
\text { (December) }\end{array}$ & $\begin{array}{l}\text { The Insurance } \\
\text { Industry and } \\
\text { Systemic Risk: } \\
\text { Evidence and } \\
\text { Discussion } \\
/ \\
\text { Working Paper }\end{array}$ & $\begin{array}{l}\text { - Systemic risk } \\
\text { - Life, non-life } \\
\text { - Event study, } \\
\text { empirical study } \\
\text { (Granger- } \\
\text { causality tests) }\end{array}$ & $\begin{array}{l}\text { What are the } \\
\text { systemic effects } \\
\text { of insurance } \\
\text { companies? } \\
\text { - What kind of } \\
\text { regulation is } \\
\text { appropriate? }\end{array}$ & $\begin{array}{l}\text { - Insurers do not contribute to systemic risk, } \\
\text { since duration of assets and liabilities are more } \\
\text { closely matched than in the case of banks } \\
\text { - Event studies show no indication that insurers } \\
\text { contribute to systemic risk nor do Granger- } \\
\text { causality tests (however, insurers are victims } \\
\text { just like other market participants) } \\
\text { - Stock market returns of banks can explain } \\
\text { stock market returns of insurers, but not vice } \\
\text { versa } \\
\text { - No institution should be classified too big to } \\
\text { fail, since this would lead to moral hazard } \\
\text { - Financial guarantees should be minimized in } \\
\text { any new regulation }\end{array}$ \\
\hline 9 & \begin{tabular}{|l|} 
Scott E. \\
Harrington
\end{tabular} & \begin{tabular}{|l|}
2011 \\
(December)
\end{tabular} & \begin{tabular}{|l|} 
Insurance \\
Regulation and the \\
Dodd-Frank Act \\
$/$ \\
Working Paper
\end{tabular} & $\begin{array}{l}\text { - Regulation } \\
\text { - Life, non-life, } \\
\text { reinsurance } \\
\text { - Qualitative } \\
\text { discussion }\end{array}$ & $\begin{array}{l}\text { - Discussion of the } \\
\text { Dodd-Frank Act } \\
\text { and systemic risk } \\
\text { - How should } \\
\text { regulation be } \\
\text { framed? }\end{array}$ & $\begin{array}{l}\text { - Regulation should take differences between } \\
\text { insurers and banks into account, especially the } \\
\text { facts that the insurance industry’s contribution } \\
\text { to systemic risk is lower and its market } \\
\text { discipline higher in comparison with the } \\
\text { banking industry } \\
\text { - Stronger financial guarantees for insurers } \\
\text { increase moral hazard } \\
\text { - No insurer should be labelled systemically } \\
\text { important, since this would create moral } \\
\text { hazard } \\
\text { - Federal Insurance Office should consider: } \\
\text { modernisation of regulation, promoting market } \\
\text { discipline, policyholder guarantees, capital } \\
\text { requirements, and group supervision }\end{array}$ \\
\hline 10 & $\begin{array}{l}\text { J. David } \\
\text { Cummins, } \\
\text { Ran Wei, } \\
\text { Xiaoying Xie }\end{array}$ & $\begin{array}{l}2012 \\
\text { (January) }\end{array}$ & \begin{tabular}{|l|} 
Financial Sector \\
Integration and \\
Information \\
Spillovers: Effects \\
of Operational \\
Risk Events on \\
U.S. Banks and \\
Insurers \\
$/$ \\
Working Paper \\
\end{tabular} & $\begin{array}{l}\text { - Contagion } \\
\text { - Life, non-life } \\
\text { - Event study and } \\
\text { weighted least } \\
\text { squares } \\
\text { regressions for } \\
\text { explaining the } \\
\text { cumulative } \\
\text { abnormal returns }\end{array}$ & $\begin{array}{l}\text { - Does the } \\
\text { announcement of } \\
\text { an operational } \\
\text { loss event of a } \\
\text { financial services } \\
\text { company have an } \\
\text { impact on other } \\
\text { companies in the } \\
\text { market? }\end{array}$ & $\begin{array}{l}\text { - } 415 \text { bank events and } 158 \text { insurance events } \\
\text { between } 1978 \text { and } 2010 \text { are analysed } \\
\text { - Operational loss announcements of banks and } \\
\text { insurers have intra- and inter-industry wide } \\
\text { negative effects } \\
\text { - Contagion effects identified by the event } \\
\text { studies seem to be information based; } \\
\text { regressions show that investors can } \\
\text { differentiate to what degree a particular } \\
\text { institution is affected }\end{array}$ \\
\hline 11 & $\begin{array}{l}\text { Wolfgang } \\
\text { Bach, } \\
\text { Tristan } \\
\text { Nguyen }\end{array}$ & 2012 & $\begin{array}{l}\text { On the Systemic } \\
\text { Relevance of the } \\
\text { Insurance } \\
\text { Industry: Is a } \\
\text { Macro Prudential } \\
\text { Insurance }\end{array}$ & $\begin{array}{l}\text { - Regulation } \\
\text { - Life, non-life, } \\
\text { reinsurance } \\
\text { - Qualitative } \\
\text { discussion }\end{array}$ & $\begin{array}{l}\text { Is a system- } \\
\text { oriented } \\
\text { regulation } \\
\text { necessary? }\end{array}$ & $\begin{array}{l}\text { - Even though traditional insurance activities } \\
\text { might not be systemically risky, macro- } \\
\text { prudential regulation is necessary due to } \\
\text { - Economic costs if insurance markets are } \\
\text { impaired } \\
\text { - High public interest in the availability of }\end{array}$ \\
\hline
\end{tabular}




\begin{tabular}{|c|c|c|c|c|c|c|}
\hline & & & \begin{tabular}{|l|} 
Regulation \\
Necessary? \\
$/$ \\
Journal of Applied \\
Finance \& \\
Banking \\
\end{tabular} & & & $\begin{array}{l}\text { large insurance capacity } \\
\text { - Providing insurance is a systemic relevant } \\
\text { function }\end{array}$ \\
\hline 12 & Etti Baranoff & 2012 & $\begin{array}{l}\text { An Analysis of the } \\
\text { AIG Case: } \\
\text { Understanding } \\
\text { Systemic Risk and } \\
\text { its Relation to } \\
\text { Insurance } \\
/ \\
\text { Journal of } \\
\text { Insurance } \\
\text { Regulation }\end{array}$ & $\begin{array}{l}\text { - AIG case } \\
\text { - Life, non-life } \\
\text { - Qualitative } \\
\text { discussion based } \\
\text { on descriptive } \\
\text { statistics }\end{array}$ & $\begin{array}{l}\text { What were the } \\
\text { internal and } \\
\text { external factors } \\
\text { for the distress of } \\
\text { AIG? }\end{array}$ & $\begin{array}{l}\text { - Internal factors: (a) dependency on credit } \\
\text { ratings based on insurance operations, (b) } \\
\text { regulatory arbitrage, (c) poor financial models, } \\
\text { (d) poor CDS contracts, (e) CDS growth, and } \\
\text { (f) poor internal risk management and controls } \\
\text { - External factors: (a) free markets philosophy, } \\
\text { (b) 'everyone deserves to own a home’ } \\
\text { ideology, (c) trust in credit ratings, (d) poor } \\
\text { banking regulation, (e) no derivatives } \\
\text { regulation, and (f) growth of bundling } \\
\text { securities with poor underwriting standards } \\
\text { - CDS writing contributed to systemic risk } \\
\text { - Securities lending did not contribute to } \\
\text { systemic risk but exacerbated the situation } \\
\text { - Insurance operations do not contribute to } \\
\text { systemic risk }\end{array}$ \\
\hline 13 & $\begin{array}{l}\text { Monica Billio, } \\
\text { Mila } \\
\text { Getmansky, } \\
\text { Andrew W. } \\
\text { Lo, } \\
\text { Loriana } \\
\text { Pelizzon }\end{array}$ & 2012 & \begin{tabular}{|l|} 
Econometric \\
Measures of \\
Connectedness \\
and Systemic Risk \\
in the Finance and \\
Insurance Sectors \\
$/$ \\
Journal of \\
Financial \\
Economics
\end{tabular} & $\begin{array}{l}\text { - Contagion } \\
\text { - Life, non-life, } \\
\text { reinsurance } \\
\text { - Empirical study } \\
\text { (principal } \\
\text { component } \\
\text { analysis and } \\
\text { Granger-causality } \\
\text { tests) that } \\
\text { measures the } \\
\text { interconnectednes } \\
\text { s of stock market } \\
\text { returns between } \\
\text { financial } \\
\text { institutions } \\
\end{array}$ & $\begin{array}{l}\text { - Are banks, } \\
\text { insurers, hedge } \\
\text { funds, and } \\
\text { brokers } \\
\text { interconnected? } \\
\text { - How to quantify } \\
\text { systemic risk? }\end{array}$ & $\begin{array}{l}\text { - The } 25 \text { largest banks, insurers, hedge funds, } \\
\text { and brokers in the world are analysed between } \\
1996 \text { and } 2008 \\
\text { - Stock market returns of banks, insurers, hedge } \\
\text { funds, and brokers have become highly } \\
\text { interconnected over the last decade } \\
\text { - Banks and insurers are especially prone to } \\
\text { transmit shocks and therefore contribute to } \\
\text { systemic risk } \\
\text { - Interconnectedness as an indicator of systemic } \\
\text { risk can be successfully measured by principal } \\
\text { components analysis and Granger-causality } \\
\text { tests }\end{array}$ \\
\hline 14 & $\begin{array}{l}\text { Faith R. } \\
\text { Neale, } \\
\text { Pamela } \\
\text { Peterson } \\
\text { Drake, } \\
\text { Patrick } \\
\text { Schorno, } \\
\text { Elias Semaan }\end{array}$ & $\begin{array}{l}2012 \\
\text { (August) }\end{array}$ & $\begin{array}{l}\text { Insurance and } \\
\text { Interconnectednes } \\
\text { s in the Financial } \\
\text { Services Industry } \\
\text { / } \\
\text { Working Paper }\end{array}$ & $\begin{array}{l}\text { - } \text { Contagion } \\
\text { - Life, non-life, } \\
\text { reinsurance } \\
\text { - Empirical study } \\
\text { (principal } \\
\text { components } \\
\text { analysis and } \\
\text { Granger-causality } \\
\text { test) that } \\
\text { measures the } \\
\text { interconnectednes } \\
\text { s of stock market } \\
\text { returns between } \\
\text { financial } \\
\text { institutions } \\
\end{array}$ & $\begin{array}{l}\text { - Are insurance } \\
\text { companies } \\
\text { interconnected } \\
\text { with the financial } \\
\text { services industry? }\end{array}$ & $\begin{array}{l}\text { - U.S. financial institutions are analysed } \\
\text { between } 1994 \text { and } 2010 \\
\text { - Insurance companies became more interrelated } \\
\text { with other financial services firms over time } \\
\text { - Insurance companies have to be differentiated } \\
\text { according to their line of business to } \\
\text { understand the interconnectedness of the } \\
\text { insurance sector } \\
\text { - Companies involved in life insurance and } \\
\text { financial guarantees are interconnected most } \\
\text { with the financial services industry and it can } \\
\text { be concluded that the interconnectedness } \\
\text { between insurance and other institutions can } \\
\text { be attributed to these lines }\end{array}$ \\
\hline 15 & $\begin{array}{l}\text { Andreas A. } \\
\text { Jobst }\end{array}$ & (December) & $\begin{array}{l}\text { Systemic Risk in } \\
\text { the Insurance } \\
\text { Sector-A Review } \\
\text { of General Issues } \\
\text { and Some } \\
\text { Findings on Large } \\
\text { Insurers in } \\
\text { Bermuda } \\
/ \\
\text { Working Paper }\end{array}$ & $\begin{array}{l}\text { - Regulation and } \\
\text { systemic risk } \\
\text { - Non-life, } \\
\text { reinsurance } \\
\text { - Qualitative } \\
\text { discussion based } \\
\text { on descriptive } \\
\text { statistics }\end{array}$ & $\begin{array}{l}\text { - Are the current } \\
\text { systemic risk } \\
\text { indicators } \\
\text { suggested by the } \\
\text { IAIS/industry } \\
\text { sufficient? } \\
\text { - Do (re)insurers } \\
\text { from Bermuda } \\
\text { contribute to } \\
\text { systemic risk? }\end{array}$ & $\begin{array}{l}\text { - Both indicator approaches proposed by the } \\
\text { IAIS and the industry to identify systemically } \\
\text { risky business activities as well as institutions } \\
\text { have shortcomings; the state of the } \\
\text { environment affecting the resilience of the } \\
\text { insurance industry is neglected as well as the } \\
\text { impact of transmission mechanisms } \\
\text { - High liquidity buffers and low holdings of } \\
\text { speculative derivatives indicate that the } \\
\text { insurance industry of Bermuda neither } \\
\text { contributes to systemic risk nor is vulnerable } \\
\text { to impairments of the financial system }\end{array}$ \\
\hline 16 & \begin{tabular}{|l|} 
Fang Chen, \\
Xuanjuan \\
Chen, \\
Zhenzhen Sun, \\
Tong Yu, \\
Ming Zhong
\end{tabular} & 2013 & $\begin{array}{l}\text { Systemic Risk, } \\
\text { Financial Crisis, } \\
\text { and Credit Risk } \\
\text { Insurance } \\
/ \\
\text { The Financial } \\
\text { Review }\end{array}$ & \begin{tabular}{l|} 
- Contagion \\
- Life, non-life \\
- Systemic risk \\
measure \\
calculation (MES, \\
BANKBETA) \\
and empirical \\
study (panel \\
regressions of \\
credit insurers' \\
\end{tabular} & $\begin{array}{l}\text { - How were credit } \\
\text { risk insurers } \\
\text { affected by the } \\
\text { financial crisis in } \\
\text { comparison to life } \\
\text { and non-life } \\
\text { insurers? } \\
\text { - Do credit risk } \\
\text { insurers transmit } \\
\text { shocks? }\end{array}$ & $\begin{array}{l}\text { - } 20 \text { insurers are identified that sell either CDS, } \\
\text { offer financial guarantees, or both; } 77 \\
\text { property-casualty insurers and } 17 \text { life insurers } \\
\text { are used as comparisons; sample period is } \\
\text { between } 2006 \text { and } 2009 \\
\text { - During the financial crisis (2007-2009), } \\
\text { performance (stock market return and return } \\
\text { on assets) of credit risk insurers is substantially } \\
\text { worse than the one of property-casualty or life } \\
\text { insurers }\end{array}$ \\
\hline
\end{tabular}




\begin{tabular}{|c|c|c|c|c|c|c|}
\hline & & & & $\begin{array}{l}\text { stock market } \\
\text { return on systemic } \\
\text { risk measures and } \\
\text { other company } \\
\text { characteristics/bo } \\
\text { nd spreads on } \\
\text { downgrading of } \\
\text { guaranteeing } \\
\text { insurer) }\end{array}$ & & $\begin{array}{l}\text { - MES can explain bad performance of credit } \\
\text { risk insurers during the financial crisis } \\
\text { - Rating downgrades of credit risk insurers lead } \\
\text { to rating downgrades of insured bonds }\end{array}$ \\
\hline 17 & $\begin{array}{l}\text { Hua Chen, } \\
\text { J. David } \\
\text { Cummins, } \\
\text { Krupa S. } \\
\text { Viswanathan, } \\
\text { Mary A. } \\
\text { Weiss }\end{array}$ & 2013 & $\begin{array}{l}\text { Systemic Risk and } \\
\text { the } \\
\text { Interconnectednes } \\
\text { s Between Banks } \\
\text { and Insurers: An } \\
\text { Econometric } \\
\text { Analysis } \\
\text { / } \\
\text { Journal of Risk } \\
\text { and Insurance }\end{array}$ & \begin{tabular}{l|} 
- Contagion \\
- Life, non-life \\
- Systemic risk \\
measure \\
calculation (DIP, \\
use of Granger- \\
causality tests to \\
evaluate which \\
institutions cause \\
systemic risk)
\end{tabular} & $\begin{array}{l}\text { Are insurers a } \\
\text { source or a victim } \\
\text { of systemic risk? }\end{array}$ & $\begin{array}{l}\text { - } 33 \text { U.S. financial institutions are analysed } \\
\text { between } 2002 \text { and } 2008 \\
\text { - In contrast to banks, insurers seem not to cause } \\
\text { systemic risk, but are vulnerable to a banking } \\
\text { crisis } \\
\text { - After adjusting for heteroskedasticity, } \\
\text { Granger-causality tests on risk measures based } \\
\text { on CDS spreads show that banks have a much } \\
\text { larger impact with a longer duration on } \\
\text { insurers than vice versa } \\
\text { - Results are confirmed by stress tests } \\
\text { - Banks and insurers are strongly interconnected }\end{array}$ \\
\hline 18 & $\begin{array}{l}\text { Hua Chen, } \\
\text { J. David } \\
\text { Cummins, } \\
\text { Krupa S. } \\
\text { Viswanathan, } \\
\text { Mary A. } \\
\text { Weiss }\end{array}$ & $\begin{array}{l}2013 \\
\text { (February) }\end{array}$ & $\begin{array}{l}\text { Systemic Risk } \\
\text { Measures in the } \\
\text { Insurance } \\
\text { Industry: A } \\
\text { Copula Approach } \\
\text { / } \\
\text { Working Paper }\end{array}$ & $\begin{array}{l}\text { - Systemic risk } \\
\text { measures } \\
\text { - Life, non-life } \\
\text { - Systemic risk } \\
\text { measure } \\
\text { calculation } \\
\text { ( } \Delta \text { CoVaR, MES, } \\
\text { and SRISK) }\end{array}$ & •- - & $\begin{array}{l}\text { - } 40 \text { U.S insurers are analysed between } 2002 \\
\text { and } 2011 \\
\text { - Four systemic risk measures- } \Delta \mathrm{CoV} \text { aR, } \\
\text { modified } \Delta \mathrm{CoVaR}, \mathrm{MES} \text {, and SRISK-are } \\
\text { estimated with the help of copula models } \\
\text { - Insurers can be systemically risky because } \\
\text { financial risk measures for insurers peak in } \\
\text { times of finical crisis } \\
\text { - Life-health insurers respond more significantly } \\
\text { to negative financial market conditions than do } \\
\text { property-casualty insurers }\end{array}$ \\
\hline 19 & $\begin{array}{l}\text { David } \\
\text { Cummins, } \\
\text { Mary A. } \\
\text { Weiss }\end{array}$ & $\begin{array}{l}2013 \\
\text { (March) }\end{array}$ & $\begin{array}{l}\text { Systemic Risk and } \\
\text { Regulation of the } \\
\text { U.S. Insurance } \\
\text { Industry } \\
\text { / } \\
\text { Working Paper }\end{array}$ & $\begin{array}{l}\text { - Systemic risk } \\
\text { - Life, non-life, } \\
\text { reinsurance } \\
\text { - Qualitative } \\
\text { discussion based } \\
\text { on descriptive } \\
\text { statistics, } \\
\text { systemic risk } \\
\text { measure } \\
\text { calculation } \\
\text { (SRISK, OLS } \\
\text { regressions of } \\
\text { systemic risk } \\
\text { measure on } \\
\text { company } \\
\text { characteristics) }\end{array}$ & $\begin{array}{l}\text { - Does the U.S. } \\
\text { insurance industry } \\
\text { contribute to } \\
\text { systemic risk or is } \\
\text { it vulnerable to } \\
\text { impairments of } \\
\text { the financial } \\
\text { system? } \\
\text { - Which } \\
\text { characteristics } \\
\text { determine the } \\
\text { vulnerability of an } \\
\text { insurer to crisis? }\end{array}$ & $\begin{array}{l}\text { - U.S. insurers are analysed between } 2001 \text { and } \\
2011 \\
\text { - Core property-casualty insurance and } \\
\text { reinsurance activities do not contribute to } \\
\text { systemic risk } \\
\text { - Most core life insurance activities do not } \\
\text { contribute to systemic risk-except separate } \\
\text { accounts and group annuities } \\
\text { - The following non-core insurance activities } \\
\text { can contribute to systemic risk } \\
\text { - Trading in derivatives } \\
\text { - Asset lending and management } \\
\text { - Financial guarantees } \\
\text { - SRISK calculations and regressions on } \\
\text { characteristics of insurers show that non-core } \\
\text { insurance activities, size, MBS underwriting, } \\
\text { and total reinsurance underwriting can explain } \\
\text { vulnerability to crisis }\end{array}$ \\
\hline 20 & $\begin{array}{l}\text { Gregor N. F. } \\
\text { Weiß, Janina } \\
\text { Mühlnickel }\end{array}$ & $\begin{array}{l}2013 \\
\text { (May) }\end{array}$ & $\begin{array}{l}\text { Consolidation and } \\
\text { Systemic Risk in } \\
\text { the International } \\
\text { Insurance Industry } \\
\text { / Working Paper }\end{array}$ & $\begin{array}{l}\text { - Systemic risk } \\
\text { - Life, non-life } \\
\text { - Systemic risk } \\
\text { measure } \\
\text { calculation (MES, } \\
\text { LTD before and } \\
\text { after M\&A } \\
\text { activity), } \\
\text { empirical study } \\
\text { (OLS regression } \\
\text { of changes in } \\
\text { systemic risk } \\
\text { measure on } \\
\text { company } \\
\text { characteristics) } \\
\end{array}$ & $\begin{array}{l}\text { - Do M\&A } \\
\text { activities increase } \\
\text { systemic risk? } \\
\text { - What } \\
\text { determinants can } \\
\text { explain changes } \\
\text { in the level of } \\
\text { systemic risk after } \\
\text { M\&A activities? }\end{array}$ & $\begin{array}{l}\text { - } 409 \text { international, domestic, and cross-border } \\
\text { mergers are analysed between } 1984 \text { and } 2010 \\
\text { - There are mixed results; if consolidation leads } \\
\text { to higher systemic risk (measured by LTD), } \\
\text { however, the vulnerability of insurers to } \\
\text { impairments of the financial system increases } \\
\text { (measured by MES) } \\
\text { - Firm size, leverage, and diversification can } \\
\text { explain changes in systemic risk measures }\end{array}$ \\
\hline 21 & \begin{tabular}{|l|} 
Martin F. \\
Grace, Jannes \\
Rauch, Sabine \\
Wende
\end{tabular} & $\begin{array}{l}2013 \\
\text { (July) }\end{array}$ & $\begin{array}{l}\text { Systemic Risk and } \\
\text { Intercon- } \\
\text { nectedness in the } \\
\text { Financial Industry: } \\
\text { Implications on } \\
\text { Regulation of } \\
\text { Financial } \\
\text { Conglomerates } \\
\end{array}$ & $\begin{array}{l}\text { - Systemic risk } \\
\text { - Life, non-life } \\
\text { - Event study }\end{array}$ & $\begin{array}{l}\text { - Can insurance- } \\
\text { specific events } \\
\text { contribute to } \\
\text { systemic risk? }\end{array}$ & $\begin{array}{l}\text { - } 12 \text { insurance-specific events are analysed } \\
\text { between } 2001 \text { and 2012, which include terror } \\
\text { attacks, natural catastrophes, frauds, and } \\
\text { financial bailouts } \\
\text { - In comparison to the S\&P 500, almost no } \\
\text { significant abnormal returns for insurers and } \\
\text { banks can be identified } \\
\text { - There is only a low degree of } \\
\text { interconnectedness between the different }\end{array}$ \\
\hline
\end{tabular}




\begin{tabular}{|c|c|c|c|c|c|c|}
\hline & & & Working Paper & & & $\begin{array}{l}\text { financial sectors } \\
\text { - No evidence is found that insurance-specific } \\
\text { events contribute to systemic risk }\end{array}$ \\
\hline 22 & \begin{tabular}{|l|} 
Etti Baranoff, \\
Daniel \\
Haefeli, \\
Thomas Sager
\end{tabular} & $\begin{array}{l}2013 \\
\text { (August) }\end{array}$ & $\begin{array}{l}\text { Surrenders in the } \\
\text { Life Insurance } \\
\text { Industry: A } \\
\text { Systemic Risk of } \\
\text { Runs? } \\
\text { Working Paper }\end{array}$ & $\begin{array}{l}\text { - Systemic risk } \\
\text { - Life } \\
\text { - Qualitative } \\
\text { discussion based } \\
\text { on descriptive } \\
\text { statistics, scenario } \\
\text { analysis (potential } \\
\text { cash outflows in } \\
\text { the life insurance } \\
\text { industry due to } \\
\text { policy } \\
\text { cancellations are } \\
\text { compared with } \\
\text { available } \\
\text { liquidity) }\end{array}$ & $\begin{array}{l}\text { - Is a potential run } \\
\text { on life insurers a } \\
\text { systemic risk? }\end{array}$ & $\begin{array}{l}\text { - Between } 2001 \text { and 2011, U.S. life insurers } \\
\text { were always able to survive cash outflows due } \\
\text { to the cancellation of contracts without selling } \\
\text { assets } \\
\text { - Simulations based on the historical distribution } \\
\text { of lapse rates show the same results } \\
\text { - Only if lapse rates were } 10 \text { times higher, } \\
\text { would assets have to be sold before maturity; } \\
\text { however, in comparison to the whole bond } \\
\text { market, the assets on sale would only be a } \\
\text { small fraction }\end{array}$ \\
\hline 23 & \begin{tabular}{|l|} 
Gregor N. F. \\
Weiß, Denefa \\
Bostandzic, \\
Felix \\
Irresberger \\
\end{tabular} & \begin{tabular}{|l|}
2013 \\
(August)
\end{tabular} & $\begin{array}{l}\text { Catastrophe Bonds } \\
\text { and Systemic Risk } \\
/ \\
\text { Working Paper }\end{array}$ & $\begin{array}{l}\text { - Systemic risk } \\
\text { - Reinsurance } \\
\text { - Systemic risk } \\
\text { measure } \\
\text { calculation } \\
\text { ( } \triangle \text { CoVaR, MES, } \\
\text { SRISK) before } \\
\text { and after the } \\
\text { issuing of cat } \\
\text { bonds, empirical } \\
\text { study (cross- } \\
\text { sectional } \\
\text { regression } \\
\text { analysis of } \\
\text { changes in the } \\
\text { systemic risk } \\
\text { measure on issuer } \\
\text { characteristics) } \\
\end{array}$ & $\begin{array}{l}\text { Does the issuing } \\
\text { of catastrophe } \\
\text { bonds increase or } \\
\text { decrease the } \\
\text { systemic risk } \\
\text { contribution of } \\
\text { insurers? }\end{array}$ & $\begin{array}{l}\text { - } 176 \text { cat bonds and their issuers are analysed } \\
\text { between } 1996 \text { and } 2013 \\
\text { - The issuing of cat bonds neither increases nor } \\
\text { decreases the systemic risk contribution of an } \\
\text { insurer or its vulnerability to impairments of } \\
\text { the financial system (results not significant) } \\
\text { - Pre-issue leverage, higher firm valuation, and } \\
\text { previous cat bond issues decrease changes in } \\
\text { systemic risk (not significant) after issuing cat } \\
\text { bonds }\end{array}$ \\
\hline 24 & $\begin{array}{l}\text { Robert W. } \\
\text { Klein }\end{array}$ & 2013 & $\begin{array}{l}\text { Insurance Market } \\
\text { Regulation: } \\
\text { Catastrophe Risk, } \\
\text { Competition and } \\
\text { Systemic Risk } \\
/ \\
\text { Handbook of } \\
\text { Insurance }\end{array}$ & $\begin{array}{l}\text { - Regulation } \\
\text { - Life, non-life, } \\
\text { reinsurance } \\
\text { Qualitative } \\
\text { discussion based } \\
\text { on literature } \\
\text { review }\end{array}$ & $\begin{array}{l}\text { - Overview of } \\
\text { insurance } \\
\text { regulation } \\
\text { How to respond } \\
\text { to risks related to } \\
\text { competition and } \\
\text { catastrophes as } \\
\text { well as systemic } \\
\text { ones? }\end{array}$ & $\begin{array}{l}\text { - Core activities of insurance companies do not } \\
\text { contribute to systemic risk } \\
\text { - Life insurers are exposed to systemic risk due } \\
\text { to their holdings of MBSs, privately placed } \\
\text { bonds, minimum interest guarantees, and high } \\
\text { leverage } \\
\text { - CDSs (non-traditional activities) can } \\
\text { contribute to systemic risk } \\
\text { - In-/solvency and market conduct regulation } \\
\text { desirable }\end{array}$ \\
\hline 25 & Denis Kessler & $\begin{array}{l}2013 \\
\text { (forth- } \\
\text { coming) }\end{array}$ & $\begin{array}{l}\text { Why } \\
\text { (Re)insurance is } \\
\text { Not Systemic } \\
\text { / } \\
\text { Journal of Risk } \\
\text { and Insurance }\end{array}$ & $\begin{array}{l}\text { - Systemic risk } \\
\text { - Reinsurance } \\
\text { - Qualitative } \\
\text { discussion }\end{array}$ & $\begin{array}{l}\text { - Does reinsurance } \\
\text { contribute to } \\
\text { systemic risk? }\end{array}$ & $\begin{array}{l}\text { - Reinsurance does not contribute to systemic } \\
\text { risk } \\
\text { - Insolvencies of reinsurers are lengthy and } \\
\text { orderly processes } \\
\text { - Claims settlements and cash outflows are } \\
\text { conditional on loss events and pre-funded } \\
\text { - Life insurance guarantee funds and lapse } \\
\text { fees prevent ‘insurance runs’ in case of life } \\
\text { insurance activities } \\
\text { - Retrocession spirals are unlikely due to the } \\
\text { hierarchical structure of the reinsurance } \\
\text { market } \\
\text { - Underwritten risks are diversified } \\
\text { (uncorrelated) } \\
\end{array}$ \\
\hline 26 & $\begin{array}{l}\text { Gregor N. F. } \\
\text { Weiß, Janina } \\
\text { Mühlnickel }\end{array}$ & 2014 & $\begin{array}{l}\text { Why Do Some } \\
\text { Insurers Become } \\
\text { Systemically } \\
\text { Relevant? } \\
\\
\text { Journal } \\
\text { of } \\
\text { Financial } \\
\text { Stability }\end{array}$ & $\begin{array}{l}\text { - Systemic risk } \\
\text { - Life, non-life, } \\
\text { reinsurance } \\
\text { - Systemic risk } \\
\text { measure } \\
\text { calculation } \\
\text { ( } \Delta \text { CoVaR, MES, } \\
\text { SRISK), } \\
\text { empirical study }\end{array}$ & $\begin{array}{l}\text { Do insurers } \\
\text { contribute to } \\
\text { systemic risk? } \\
\text { Which factors } \\
\text { determine the } \\
\text { contribution of an } \\
\text { insurer to } \\
\text { systemic risk? }\end{array}$ & $\begin{array}{l}\text { - } 89 \text { publicly listed U.S. insurers are analysed } \\
\text { with data from } 2006 \\
\text { - Insurers can contribute to systemic risk and are } \\
\text { vulnerable to impairments of the financial } \\
\text { system } \\
\text { - Size and other income are the only significant } \\
\text { factors of the IAIS criteria in determining the } \\
\text { systemic risk contribution of an insurer as well } \\
\text { as its vulnerability to impairments of the }\end{array}$ \\
\hline
\end{tabular}




\begin{tabular}{|c|c|c|c|c|c|c|}
\hline & & & & $\begin{array}{l}\text { (OLS and probit } \\
\text { regressions of } \\
\text { systemic risk } \\
\text { measures and } \\
\text { TARP funding on } \\
\text { approximated } \\
\text { IAIS indicators } \\
\text { for systemic risk) }\end{array}$ & & financial system \\
\hline 27 & $\begin{array}{l}\text { J. David } \\
\text { Cummins, } \\
\text { Mary A. } \\
\text { Weiss }\end{array}$ & $\begin{array}{l}2014 \\
\text { (forth- } \\
\text { coming) }\end{array}$ & $\begin{array}{l}\text { Systemic Risk and } \\
\text { the U.S. Insurance } \\
\text { Sector } \\
\text { / } \\
\text { Journal of Risk } \\
\text { and Insurance }\end{array}$ & $\begin{array}{l}\text { - Systemic risk } \\
\text { - Life, non-life, } \\
\text { reinsurance } \\
\text { - Qualitative } \\
\text { discussion based } \\
\text { on descriptive } \\
\text { statistics }\end{array}$ & $\begin{array}{l}\text { - Does the U.S. } \\
\text { insurance sector } \\
\text { significantly } \\
\text { contribute to } \\
\text { systemic risk? }\end{array}$ & $\begin{array}{l}\text { - Traditional activities of insurers do not } \\
\text { contribute to systemic risk, but derivatives } \\
\text { trading and financial guarantees might } \\
\text { - Life insurers are vulnerable due to } \\
\text { leverage/MBSs to intra-sector crises } \\
\text { - Both life and property-casualty insurers are } \\
\text { vulnerable to reinsurance crisis } \\
\text { - Insurance group supervision is needed to } \\
\text { regulate non-core activities effectively }\end{array}$ \\
\hline 28 & $\begin{array}{l}\text { Robert Engle, } \\
\text { Eric Jondeau, } \\
\text { Michael } \\
\text { Rockinger }\end{array}$ & $\begin{array}{l}2014 \\
\text { (forth- } \\
\text { coming) }\end{array}$ & $\begin{array}{l}\text { Systemic Risk in } \\
\text { Europe } \\
/ \\
\text { Review of Finance }\end{array}$ & $\begin{array}{l}\text { - Systemic risk } \\
\text { measures } \\
\text { - Life, non-life, } \\
\text { reinsurance } \\
\text { - Systemic risk } \\
\text { measure } \\
\text { calculation } \\
\text { (LRMES and } \\
\text { SRISK) }\end{array}$ & $\begin{array}{l}\text { - Which European } \\
\text { financial } \\
\text { institutions are } \\
\text { risky? }\end{array}$ & $\begin{array}{l}\text { - } 196 \text { European financial institutions are } \\
\text { analysed for the period from } 1990 \text { to } 2012 \\
\text { - Based on LRMES, an approximately } 40 \% \\
\text { decline in world markets leads to an } \\
\text { approximately negative return of } 40 \% \text { for } \\
\text { European banking and insurance companies } \\
\text { - Based on SRISK, the total amount of capital } \\
\text { needed by the European financial system in } \\
\text { times of crisis (capital shortfall) is calculated } \\
\text { - } 80 \% \text { can be attributed to the banking sector } \\
\text { - } 18 \% \text { can be attributed to the insurance sector }\end{array}$ \\
\hline 29 & \begin{tabular}{|l|l} 
T. R. Berry- & 2 \\
Stölzle, \\
Gregory P. \\
Nini, \\
Sabine Wende
\end{tabular} & $\begin{array}{l}2014 \\
\text { (forth- } \\
\text { coming) }\end{array}$ & \begin{tabular}{|l|} 
External \\
Financing in the \\
Life Insurance \\
Industry: Evidence \\
from the Financial \\
Crisis \\
$/$ \\
Journal of Risk \\
and Insurance
\end{tabular} & $\begin{array}{l}\text { - } \text { Capitalization } \\
\text { - Life } \\
\text { - Empirical study } \\
\text { (probit and fixed- } \\
\text { effects regression } \\
\text { models) to } \\
\text { identify the } \\
\text { determinants of } \\
\text { equity issuing and } \\
\text { its consequences }\end{array}$ & $\begin{array}{l}\text { - Can life insurers } \\
\text { raise external } \\
\text { capital in times of } \\
\text { crisis? } \\
\text { - What are causes } \\
\text { and consequences } \\
\text { of capital raising? }\end{array}$ & $\begin{array}{l}\text { - } 6,960 \text { U.S. insurers are considered between } \\
1997 \text { and } 2010 \\
\text { - Capital is mostly raised if net income is } \\
\text { negative or unfunded growth opportunities } \\
\text { exist } \\
\text { - Insurers had no difficulty in raising money } \\
\text { during the crisis; there is no evidence that } \\
\text { insurers had more difficulty in raising capital } \\
\text { between } 2007 \text { and } 2009 \text { than at any other } \\
\text { given period } \\
\text { - Open TARP funds for insurers were } \\
\text { unnecessary } \\
\text { - Additional regulation for insurers is not } \\
\text { needed since they could deal very well with } \\
\text { the crisis }\end{array}$ \\
\hline 30 & $\begin{array}{l}\text { Sojung C. } \\
\text { Park, } \\
\text { Xiaoying Xie }\end{array}$ & $\begin{array}{l}2014 \\
\text { (forth- } \\
\text { coming) }\end{array}$ & $\begin{array}{l}\text { Reinsurance and } \\
\text { Systemic Risk: } \\
\text { The Impact of } \\
\text { Reinsurer } \\
\text { Downgrading on } \\
\text { Property-Casualty } \\
\text { Insurers } \\
\text { / } \\
\text { Journal of Risk } \\
\text { and Insurance }\end{array}$ & \begin{tabular}{|l|} 
- Contagion \\
- Reinsurance \\
- Empirical study \\
(probit \\
regressions) and \\
scenario analysis \\
about hypothetical \\
equity levels of \\
insurers if major \\
reinsurers fail
\end{tabular} & $\begin{array}{l}\text { - Do reinsurer } \\
\text { downgradings } \\
\text { have an impact on } \\
\text { insurers? }\end{array}$ & $\begin{array}{l}\text { - } 516 \text { rating up- and downgrades for U.S. } \\
\text { insurers are analysed } \\
\text { - Rating downgrades of reinsurers increase } \\
\text { likelihood of rating downgrades of insurers, } \\
\text { since companies are interconnected } \\
\text { - No indication that reinsurers contribute to } \\
\text { systemic risk } \\
\text { - Scenario analysis shows that even if three } \\
\text { leading reinsures went bankrupt the market } \\
\text { would not fail }\end{array}$ \\
\hline \multicolumn{7}{|c|}{ Part B Industry Studies and Practitioner Papers } \\
\hline No. & Author & Year & \begin{tabular}{|l|} 
Title/ \\
Publication Type \\
\end{tabular} & Focus & Research Question & Main Result \\
\hline 1 & $\begin{array}{l}\text { Jean-Baptiste } \\
\text { Zufferey } \\
\text { (Experten- } \\
\text { gruppe } \\
\text { Finanzmarkt- } \\
\text { aufsicht) }\end{array}$ & 2000 & $\begin{array}{l}\text { Finanzmarkt- } \\
\text { regulierung und } \\
\text {-aufsicht in der } \\
\text { Schweiz } \\
\text { / } \\
\text { Report }\end{array}$ & $\begin{array}{l}\text { - Regulation } \\
\text { - Life, non-life, } \\
\text { reinsurance } \\
\text { - Qualitative } \\
\text { discussion }\end{array}$ & $\begin{array}{l}\text { - What are the } \\
\text { challenges for the } \\
\text { regulation of the } \\
\text { financial sector in } \\
\text { Switzerland? }\end{array}$ & $\begin{array}{l}\text { - In regard to insurance and systemic risk: } \\
\text { - Regulation of insurers should take } \\
\text { differences between banking and insurance } \\
\text { into account, not differentiate according to } \\
\text { the size of a company, and focus on the } \\
\text { protection of policyholders } \\
\text { - Contagion risks are low in insurance } \\
\text { - The insurance sector is vulnerable to } \\
\text { macroeconomic shocks } \\
\text { - Underwriting of derivatives could lead to } \\
\text { systemic risk if information asymmetries are } \\
\text { exploited by the industry }\end{array}$ \\
\hline 2 & $\begin{array}{l}\text { Patrizia Baur, } \\
\text { Rudolf Enz, } \\
\text { Aurelia Zanetti } \\
\text { (Swiss Re) }\end{array}$ & 2003 & $\begin{array}{l}\text { Reinsurance-A } \\
\text { Systemic Risk? } \\
\text { / } \\
\text { Report }\end{array}$ & $\begin{array}{l}\text { - Systemic risk } \\
\text { - Reinsurance } \\
\text { - Qualitative } \\
\text { discussion }\end{array}$ & $\begin{array}{l}\text { Does reinsurance } \\
\text { contribute to } \\
\text { systemic risk? }\end{array}$ & $\begin{array}{l}\text { - Reinsurance does not contribute to systemic } \\
\text { risk } \\
\text { - Unavailability of reinsurance not sign of } \\
\text { systemic risk but due to changes in the } \\
\text { environment }\end{array}$ \\
\hline
\end{tabular}




\begin{tabular}{|c|c|c|c|c|c|c|}
\hline & & & & & & $\begin{array}{l}\text { - Primary insurers diversify their reinsurance } \\
\text { exposure } \\
\text { - Retrocession spiral due to reinsurer } \\
\text { bankruptcies would not reach critical } \\
\text { volume } \\
\text { - In the past, insurers failed mostly due to } \\
\text { management problems and not due to } \\
\text { reinsurance failures }\end{array}$ \\
\hline 3 & \begin{tabular}{|l|} 
Financial \\
Stability Board \\
(FSB)
\end{tabular} & 2009 & $\begin{array}{l}\text { Guidance to } \\
\text { Assess the } \\
\text { Systemic } \\
\text { Importance of } \\
\text { Financial } \\
\text { Institutions, } \\
\text { Markets and } \\
\text { Instruments: } \\
\text { Initial } \\
\text { Considerations } \\
\text { / } \\
\text { Policy Guidance } \\
\end{array}$ & $\begin{array}{l}\text { - Regulation } \\
\text { - Life, non-life, } \\
\text { reinsurance } \\
\text { - Qualitative } \\
\text { discussion }\end{array}$ & $\begin{array}{l}\text { - Policy guidance } \\
\text { - Report to the G20 } \\
\text { Finance Ministers }\end{array}$ & $\begin{array}{l}\text { - Indicators for systemic risk of organizations } \\
\text { - Size } \\
\text { - Lack of substitutability } \\
\text { - Interconnectedness } \\
\text { - Institutions and markets have to be considered } \\
\text { - Indicators of financial vulnerability } \\
\text { - Leverage } \\
\text { - Liquidity risk } \\
\text { - Maturity mismatches } \\
\text { - Complexity of products and services }\end{array}$ \\
\hline 4 & $\begin{array}{l}\text { International } \\
\text { Association of } \\
\text { Insurance } \\
\text { Supervisors } \\
\text { (IAIS) }\end{array}$ & 2009 & \begin{tabular}{|l|} 
Systemic Risk and \\
the Insurance \\
Sector \\
$/$ \\
Report
\end{tabular} & $\begin{array}{l}\text { - Systemic risk } \\
\text { - Life, non-life, } \\
\text { reinsurance } \\
\text { - Qualitative } \\
\text { discussion }\end{array}$ & $\begin{array}{l}\text { - Identification of } \\
\text { further challenges } \\
\text { of insurance } \\
\text { regulators }\end{array}$ & $\begin{array}{l}\text { - Time as another aspect should be added to the } \\
\text { FSB's assessment criteria of systemic risk } \\
\text { - Insurers should be supervised on a group-wide } \\
\text { basis, which should include non-regulated } \\
\text { business activities } \\
\text { - Different business model of insurers in } \\
\text { contrast to banks has to be taken into account } \\
\text { when framing regulation policies }\end{array}$ \\
\hline 5 & $\begin{array}{l}\text { Geneva } \\
\text { Association }\end{array}$ & 2010 & \begin{tabular}{|l|} 
Systemic Risk in \\
Insurance-An \\
Analysis of \\
Insurance and \\
Financial Stability \\
$/$ \\
Report
\end{tabular} & $\begin{array}{l}\text { - Systemic risk } \\
\text { - Life, non-life, } \\
\text { reinsurance } \\
\text { - Qualitative } \\
\text { discussion based } \\
\text { on descriptive } \\
\text { statistics }\end{array}$ & $\begin{array}{l}\text { - Discussion of } \\
\text { systemic risk in } \\
\text { Solvency II } \\
\text { - Which activities } \\
\text { of insurance } \\
\text { companies } \\
\text { contribute to } \\
\text { systemic risk? } \\
\text { - How should } \\
\text { regulation be } \\
\text { framed? }\end{array}$ & $\begin{array}{l}\text { - Whether companies contribute to systemic risk } \\
\text { should be decided according to size, } \\
\text { interconnectedness, substitutability, and the } \\
\text { speed of potential liquidity outflow } \\
\text { - Regulation should focus on activities, not } \\
\text { institutions } \\
\text { - Traditional insurance activities do not } \\
\text { contribute to systemic risk } \\
\text { - Non-traditional activities can contribute to } \\
\text { systemic risk } \\
\text { - Short-term funding and securities lending } \\
\text { - Derivatives trading (e.g., CDS writing) } \\
\end{array}$ \\
\hline 6 & $\begin{array}{l}\text { Geneva } \\
\text { Association }\end{array}$ & 2010 & $\begin{array}{l}\text { Key Financial } \\
\text { Issues in Insurance } \\
/ \\
\text { Report }\end{array}$ & $\begin{array}{l}\text { - Systemic risk } \\
\text { - Life, non-life } \\
\text { - Qualitative } \\
\text { discussion based } \\
\text { on descriptive } \\
\text { statistics }\end{array}$ & $\begin{array}{l}\text { - Follow-up report } \\
\text { on the report: } \\
\text { 'Systemic Risk in } \\
\text { Insurance' }\end{array}$ & $\begin{array}{l}\text { - Severe decline in asset values would affect } \\
\text { insurance companies } \\
\text { - Traditional business model does not } \\
\text { incorporate liquidity or 'insurance run' risks } \\
\text { because } \\
\text { - There is normally no short-term funding } \\
\text { - Upfront fees exist } \\
\text { - No withdrawals at will possible } \\
\text { - Uninsurability is not a systemic risk but a } \\
\text { reflection of reality and regulation in this } \\
\text { regard would create systemic risk }\end{array}$ \\
\hline 7 & \begin{tabular}{|l|} 
International \\
Association of \\
Insurance \\
Supervisors \\
(IAIS)
\end{tabular} & 2010 & \begin{tabular}{|l|} 
Position Statement \\
on Key Financial \\
Stability Issues \\
$/$ \\
Report
\end{tabular} & $\begin{array}{l}\text { - Regulation } \\
\text { - Life, non-life, } \\
\text { reinsurance } \\
\text { - Qualitative } \\
\text { discussion }\end{array}$ & - Position statement & $\begin{array}{l}\text { - Traditional insurance business does not } \\
\text { generate systemic risk, but is affected by } \\
\text { systemic risk in other sectors } \\
\text { - Life insurers might amplify a crisis in case of } \\
\text { an equity downturn } \\
\text { - Insolvencies no problem, since policyholder } \\
\text { claims are not instantly due and no risk of fire } \\
\text { sales } \\
\text { - Cross-sectorial macro-prudent (banks + } \\
\text { insurance) supervision as well as international } \\
\text { (group-wide) supervision desirable }\end{array}$ \\
\hline 8 & $\begin{array}{l}\text { Geneva } \\
\text { Association }\end{array}$ & 2011 & \begin{tabular}{|l|} 
Variable Annuities \\
with Guarantees \\
and Use of \\
Hedging \\
$/$ \\
Insurance and \\
Finance SC10
\end{tabular} & $\begin{array}{l}\text { - Systemic risk } \\
\text { - Life } \\
\text { - Qualitative } \\
\text { discussion }\end{array}$ & $\begin{array}{l}\text { - Discussion of } \\
\text { systemic risk } \\
\text { regarding } \\
\text { annuities/hedging } \\
\text { - Do variable } \\
\text { annuities with } \\
\text { guarantees and } \\
\text { hedging activities } \\
\text { contribute to } \\
\text { systemic risk? }\end{array}$ & $\begin{array}{l}\text { - Neither variable annuities with guarantees nor } \\
\text { hedging activities are a potential source of } \\
\text { systemic risk }\end{array}$ \\
\hline 9 & $\begin{array}{l}\text { International } \\
\text { Association of }\end{array}$ & 2011 & $\begin{array}{l}\text { Insurance and } \\
\text { Financial Stability }\end{array}$ & $\begin{array}{l}\text { - Systemic risk } \\
\text { - Life, non-life, }\end{array}$ & $\begin{array}{l}\text { - Which business } \\
\text { lines of insurers }\end{array}$ & $\begin{array}{l}\text { - Life and non-life insurance activities neither } \\
\text { cause nor amplify systemic risk }\end{array}$ \\
\hline
\end{tabular}




\begin{tabular}{|c|c|c|c|c|c|c|}
\hline & $\begin{array}{l}\text { Insurance } \\
\text { Supervisors } \\
\text { (IAIS) }\end{array}$ & & / Report & $\begin{array}{l}\text { reinsurance } \\
\text { - Qualitative } \\
\text { discussion }\end{array}$ & $\begin{array}{l}\text { contribute to } \\
\text { - Howstemic risk? } \\
\text { regulation be } \\
\text { framed? }\end{array}$ & $\begin{array}{l}\text { - Non-traditional and non-insurance activities } \\
\text { like CDS writing can contribute to systemic } \\
\text { risk } \\
\text { - Group-wide supervision including insurance } \\
\text { and non-insurance businesses should be } \\
\text { established }\end{array}$ \\
\hline 10 & $\begin{array}{l}\text { Philipp Keller } \\
\text { (Geneva } \\
\text { Association) }\end{array}$ & 2011 & $\begin{array}{l}\text { Solvency II and } \\
\text { Incentives for } \\
\text { Systemic Risk } \\
\text { Exposure } \\
/ \\
\text { Progres No. } 54\end{array}$ & $\begin{array}{l}\text { - Regulation } \\
\text { - Life, non-life, } \\
\text { reinsurance } \\
\text { - Qualitative } \\
\text { discussion }\end{array}$ & $\begin{array}{l}\text { - Discussion of } \\
\text { Solvency II } \\
\text { - How will } \\
\text { Solvency II deal } \\
\text { with the future } \\
\text { risks? }\end{array}$ & $\begin{array}{l}\text { - Despite opposition, market-consistent } \\
\text { valuation of assets and liabilities should be } \\
\text { kept since in this way the highest number of } \\
\text { securities can be priced most accurately } \\
\text { - Sovereign debt risks are neglected } \\
\text { - Solvency II provides incentives to use standard } \\
\text { formula, which can cause systemic risk } \\
\text { (aligned behaviour) } \\
\text { - Solvency II provides incentives to invest in } \\
\text { illiquid and risky assets }\end{array}$ \\
\hline 11 & $\begin{array}{l}\text { Geneva } \\
\text { Association }\end{array}$ & 2012 & $\begin{array}{l}\text { Insurance and } \\
\text { Resolution in } \\
\text { Light of the } \\
\text { Systemic Risk } \\
\text { Debate } \\
\text { / } \\
\text { Report } \\
\end{array}$ & $\begin{array}{l}\text { - Systemic risk } \\
\text { - Life, non-life, } \\
\text { reinsurance } \\
\text { - Qualitative } \\
\text { discussion }\end{array}$ & $\begin{array}{l}\text { - Do failing } \\
\text { insurers } \\
\text { contribute to } \\
\text { systemic risk? }\end{array}$ & $\begin{array}{l}\text { - Impaired insurers that need to be wound up } \\
\text { generally do not contribute to systemic risk } \\
\text { - Exceptions could be mismanagement of short- } \\
\text { term funding and extensive underwriting of } \\
\text { CDS }\end{array}$ \\
\hline 12 & $\begin{array}{l}\text { International } \\
\text { Association of } \\
\text { Insurance } \\
\text { Supervisors } \\
\text { (IAIS) }\end{array}$ & 2012 & $\begin{array}{l}\text { Reinsurance and } \\
\text { Financial Stability } \\
/ / \\
\text { Report }\end{array}$ & $\begin{array}{l}\text { - Systemic risk } \\
\text { - Reinsurance } \\
\text { - Qualitative } \\
\text { discussion based } \\
\text { on descriptive } \\
\text { statistics and } \\
\text { quantitative stress } \\
\text { tests }\end{array}$ & $\begin{array}{l}\text { - Does reinsurance } \\
\text { contribute to } \\
\text { systemic risk? }\end{array}$ & $\begin{array}{l}\text { - Reinsurance does not contribute to systemic } \\
\text { risk } \\
\text { - Interconnectedness is mainly vertical } \\
\text { between reinsurers and insurers; } \\
\text { interconnectedness on a horizontal level is } \\
\text { weak } \\
\text { - Stress tests show that reinsurers can absorb } \\
\text { severe catastrophic events and financial } \\
\text { market stress simultaneously } \\
\text { - In the past, insurers did not fail due to } \\
\text { reinsurance insolvencies } \\
\text { - Engagement in insurance derivatives without } \\
\text { an insurable interest could make the insurer } \\
\text { vulnerable and be a potential cause of systemic } \\
\text { risk }\end{array}$ \\
\hline 13 & $\begin{array}{l}\text { International } \\
\text { Association of } \\
\text { Insurance } \\
\text { Supervisors } \\
\text { (IAIS) }\end{array}$ & 2012 & $\begin{array}{l}\text { Global } \\
\text { Systemically } \\
\text { Important } \\
\text { Insurers: Proposed } \\
\text { Assessment } \\
\text { Methodology } \\
/ \\
\text { Report }\end{array}$ & $\begin{array}{l}\text { - } \text { Systemic risk } \\
\text { assessment } \\
\text { - Life, non-life, } \\
\text { reinsurance } \\
\text { - Methodology } \\
\text { description }\end{array}$ & $\begin{array}{l}\text { - How to assess } \\
\text { systemically } \\
\text { important } \\
\text { insurers? } \\
\text { - How should } \\
\text { regulation be } \\
\text { framed? }\end{array}$ & $\begin{array}{l}\text { - Indicator-based assessment according to } \\
\text { - Size } \\
\text { - Global activity } \\
\text { - Interconnectedness } \\
\text { - Non-traditional and non-insurance activities } \\
\text { - Substitutability } \\
\text { - Structural proposed regulation measures } \\
\text { - Separate legal structures for non- } \\
\text { traditional/non-insurance activities } \\
\text { - Restrictions on cross-subsidies within a } \\
\text { group } \\
\text { - Disallowance of certain diversification } \\
\text { benefits from non-traditional/non-insurance } \\
\text { activities for calculating solvency } \\
\text { requirements } \\
\text { - Regulation of subsidiaries with non- } \\
\text { traditional/non-insurance activities within a } \\
\text { group }\end{array}$ \\
\hline
\end{tabular}

Table A2: Papers on systemic risk in insurance 


\section{References}

Acharya, V. V., Biggs, J., Le, H., Richardson, M., and Ryan, S. (2011) 'Systemic risk and the regulation of insurance companies', in V. V. Acharya, T. F. Cooley, M. Richardson, and I. Walter (Eds.) Regulating Wall Street-The Dodd-Frank Act and the New Architecture of Global Finance, Hoboken: John Wiley \& Sons, pp. 241-301.

Acharya, V. V., Engle, R., and Richardson, M. (2012a) 'Capital shortfall: A new approach to ranking and regulating systemic risks', American Economic Review 102(3): 59-64.

Acharya, V. V., Pederson, L. H., Philippon, T., and Richardson, M. P. (2012b) Measuring systemic risk, working paper, New York University, New York, NY.

Adrian, T., and Brunnermeier, M. K. (2011) CoVaR, working paper, Federal Reserve Bank of New York, New York, NY.

Al-Darwish, A., Hafeman, M., Impavido, G., Kemp, M., and O’Malley, P. (2011) Possible unintended consequences of Basel III and Solvency II, IMF Working Paper WP/11/187.

Allen, W. A., and Wood, G. (2006) 'Defining and achieving financial stability', Journal of Financial Stability 2(2): 152-172.

Anand, K., Gai, P., Kapadia, S., Brennan, S., and Willison M. (2013) 'A network model of financial system resilience’, Journal of Economic Behavior \& Organization 85: 219-235.

Ashby, S. (2011) 'Risk management and the global banking crisis: Lessons for insurance solvency regulation', Geneva Papers on Risk and Insurance-Issues and Practice 36(3): 330-347.

Bach, W., and Nguyen, T. (2012) 'On the systemic relevance of the insurance industry: Is a macroprudential insurance regulation necessary?’ Journal of Applied Finance \& Banking 2(1): 127-149.

Baluch, F., Mutenga, S., and Parsons, C. (2011) 'Insurance, systemic risk and the financial crisis', Geneva Papers on Risk and Insurance-Issues and Practice 36(1): 126-163.

Baranoff, E. (2012) 'An analysis of the AIG case: Understanding systemic risk and its relation to insurance', Journal of Insurance Regulation 31: 243-270.

Baranoff, E. G., Brockett, P., Sager, T. W., and Shi, B. (2011) Is the U.S. life insurance industry in danger of systemic risk by using hedging derivatives? working paper, presented at ARIA 2011 Annual Meeting, San Diego, CA.

Baranoff, E. G., Haefli, D., and Sager, T. W. (2013) Surrenders in the life insurance industry: A systemic risk of runs? working paper, presented at ARIA 2013 Annual Meeting, Washington, DC.

Barrett, R., and Ewan, J. (2006) BBA Credit Derivatives Report 2006.

Baur, P., Enz, R., and Zanetti, A. (2003) Reinsurance-A Systemic Risk? Zürich: Swiss Re. 
Benoit, S., Colletaz, G., Hurlin, C., Pérignon, C., (2013) A theoretical and empirical comparison of systemic risk measures, working paper, University of Orléans, Orléans, France.

Berry-Stölzle, T. R., Nini, G. P., and Wende, S. (2014) 'External financing in the life insurance industry: Evidence from the financial crisis', Journal of Risk and Insurance advance online publication 07 May, doi: 10.1111/jori.12042, 1-34.

Besar, D., Booth, P., Chan, K. K., Milne, K. L., and Pickles, J. (2011) 'Systemic risk in financial services’, British Actuarial Journal, 16(2): 195-300.

Biener, C., and Eling, M. (2012) 'Insurability in microinsurance markets: An analysis of problems and potential solutions', Geneva Papers on Risk and Insurance-Issues and Practice, 37: 77-107.

Billio, M., Getmansky, M., Lo, A. W., and Pelizzon, L. (2010) Econometric measures of systemic risk in the finance and insurance sectors, working paper, National Bureau of Economic Research, Cambridge, MA.

Billio, M., Getmansky, M., Lo, A. W., and Pelizzon, L. (2012) 'Econometric measures of connectedness and systemic risk in the finance and insurance sectors', Journal of Financial Economics 104(3): 535-559.

Bisias, D., Flood, M., Lo, A. W., and Valavanis, S. (2012) A survey of systemic risk analytics, working paper, MIT Operations Research Center.

Boles, C. (2009) 'Bernanke offers broad definition of systemic risk', Wall Street Journal, from http://blogs.wsj.com/economics/2009/11/18/bernanke-offers-broad-definition-ofsystemic-risk/, accessed 22 July 2013.

Brady, D. (2009) 'Bernake blasts AIG for "irresponsible bets" that led to bailouts', Washington Post, 4 March.

Brunnermeier, M., Crocket, A., Goodhart, C., Persaud, A. D., and Shin, H. (2009) The Fundamental Principles of Financial Regulation (May).

Camerer, C., and Weber, M. (1992) 'Recent developments in modelling preferences: Uncertainty and ambiguity’, Journal of Risk and Uncertainty 5(4): 325-370.

Chen, F., Chen, X., Sun, Z., Yu, T., and Zhong, M. (2013) 'Systemic risk, financial crisis, and credit risk insurance', Financial Review 48: 417-442.

Chen, H., Cummins, J. D., Viswanathan, K. S., and Weiss, M. A. (2013a) 'Systemic risk and the interconnectedness between banks and insurers: An econometric analysis', Journal of Risk and Insurance advance online publication 14 March, doi: 10.1111/j.15396975.2012.01503.x, 1-30.

Chen, H., Cummins, J. D., Viswanathan, K. S., and Weiss, M. A. (2013b) Systemic risk measures in the insurance industry: A copula approach, working paper, Temple University, Philadelphia, PA. 
Committee on Capital Markets Regulation (CCMR) (2009) The Global Financial Crisis (May).

Cummins, J. D., Wei, R., and Xie, X. (2012) Financial sector integration and information spillovers: Effects of operational risk events on U.S. banks and insurers, working paper, Temple University, Philadelphia, PA.

Cummins, J. D., and Weiss, M. A. (2009) 'Convergence of insurance and financial markets: Hybrid and securitized risk-transfer solutions’, Journal of Risk and Insurance 76(3): 493545.

Cummins, J. D., and Weiss, M. A. (2013) Systemic risk and regulation of the U.S. insurance industry, working paper, Temple University, Philadelphia, PA.

Cummins, J. D., and Weiss, M. A. (2014) 'Systemic risk and the U.S. insurance sector', Journal of Risk and Insurance advance online publication 20 March, doi: 10.1111/jori.12039: 1-39

De Bandt, O., and Hartmann, P. (2000) Systemic risk: a survey, working paper, European Central Bank, Frankfurt.

Drake, P. P., and Neale, F. R. (2011) 'Financial guarantee insurance and failures in risk management', Journal of Insurance Regulation 30(2): 29-76.

Drehmann, M., and Tarashev, N. (2011) 'Systemic importance: Some simple indicators', BIS Quarterly Review March: 25-37

Dwyer, G. D. (2009) 'What is systemic risk, anyway?' from http://macroblog.typepad.com/macroblog/2009/11/what-is-systemic-risk-anyway.html, accessed 24 July 2013.

Eling, M., Gatzert, N., and Schmeiser, H. (2008) 'The Swiss Solvency Test and its market implications', Geneva Papers on Risk and Insurance-Issues and Practice 33(3): 418439.

Eling, M., and Schmeiser, H. (2010) 'Insurance and credit crisis: Impact and ten consequences for risk management supervision', Geneva Papers on Risk and InsuranceIssues and Practice 35(1): 180-207.

Eling, M., and Schmit, J. T. (2012) 'Is there market discipline in the European insurance industry? An analysis of the German insurance market', Geneva Papers on Risk and Insurance-Issues and Practice 37(2): 9-34.

Engle, R., Jondeau, E., and Rockinger, M. (2014) 'Systemic risk in Europe', Review of Finance advance online publication 31 March, doi: doi:10.1093/rof/rfu012, 1-46.

Epermanis, K., and Harringtion, S. E. (2006) 'Market discipline in property/casualty insurance: Evidence from premium growth surrounding changes in financial strength ratings', Journal of Money, Credit and Banking 38(6): 1515-1544.

European Central Bank (2013) Financial Stability Review May 2013 (May). 
European Parliament and European Council (2009) 'Directive 2009/138/EC of the European Parliament and of the Council', Official Journal of the European Union L335: 1-55.

European Parliament and European Council (2012) 'Regulation (EU) no 236/2012 of the European Parliament and of the Council', Official Journal of the European Union I86:124.

Federal Reserve Bank of Cleveland (2013) 'Defining financial stability', from http://www.clevelandfed.org/research/topics/finstability/definition.cfm, accessed 31 July 2013.

Forbes, K. J. (2012) The big 'c': Identifying and mitigating contagion, working paper, MIT Sloan School, Cambridge, MA.

Forbes, K. J., and Rigobon, R. (2002) 'No contagion, only interdependence: Measuring stock market comovements’, Journal of Finance 57(5): 2223-2261.

FSB (2009) Report to G20 Finance Ministers and Governors-Guidance to Assess the Systemic Importance of Financial Institutions, Markets and Instruments: Initial Considerations (October).

FSB (2012) Update of Group of Global Systemically Important Banks (G-SIBs) (November). FSB (2013a) Global Systemically Important Insurers (G-SIIs) and the Policy Measures that Will Apply to Them (July).

FSB (2013b) Progress and Next Steps Towards Ending 'Too-Big-to-Fail' (TBTF) (September).

FSOC (2012) Authority to Require Supervision and Regulation of Certain Nonbank Financial Companies (April).

Geneva Association (2010a) Systemic Risk in Insurance-An Analysis of Insurance and Financial Stability (March).

Geneva Association (2010b) Key Financial Stability Issues in Insurance-An Account of the Geneva Association's Ongoing Dialogue on Systemic Risk with Regulators and PolicyMakers (July).

Geneva Association (2011) Variable Annuities with Guarantees and Use of Hedging (March). Geneva Association (2012) Insurance and Resolution in Light of the Systemic Risk Debate (February).

Grace, M. F. (2011) The insurance industry and systemic risk: Evidence and discussion, working paper, Georgia State University, Atlanta, GA.

Grace, M. F., Rauch J., and Wende, S. (2013) Systemic risk and interconnectedness in the financial industry: Implications on regulation of financial conglomerates, working paper, Georgia State University, Atlanta, GA.

Group of Ten (2001) Report on Consolidation in the Financial Sector (January) 
Haldane, A. G. (2012) The dog and the Frisbee, paper speech held at Federal Bank of Kansas City’s 36th Economic Policy Symposium, Jackson Hole, WY.

Harrington, S. E. (2004) 'Market discipline in insurance and reinsurance', in: C. Borio, W. C. Hunter, G. Kaufman, and K. Tsatsaronis (Eds.) Market Discipline Across Countries and Industries, $1^{\text {st }}$ edition, Cambridge, MA: MIT Press, pp. 159-173.

Harrington, S. E. (2009) 'The financial crisis, systemic risk, and the future of insurance regulation', Journal of Risk and Insurance 76(4): 785-819.

Harrington, S. E. (2011) Insurance regulation and the Dodd-Frank Act, working paper, Wharton School, University of Pennsylvania, Philadelphia, PA.

Heyde, F., and Neyer, U. (2010) 'Credit default swaps and the stability of the banking sector', International Review of Finance 10(1): 27-61.

Huang, X., Zhou, H., and Zhu, H. (2009) 'A framework for assessing the systemic risk of major financial institutions', Journal of Banking \& Finance 33(11): 2036-2049.

IAIS (2009) Systemic Risk and the Insurance Sector (October).

IAIS (2010) Position Statement on Key Financial Stability Issues (June).

IAIS (2011) Insurance and Financial Stability (November).

IAIS (2012a) Global Systemically Important Insurers: Proposed Assessment Methodology (May).

IAIS (2012b) Reinsurance and Financial Stability (July).

IAIS (2013a) Global Systemically Important Insurers: Initial Assessment Methodology (July).

IAIS (2013b) Global Systemically Important Insurers: Policy Measures (July).

IAIS (2014) Update on BCR Development (March).

IMF (2007) Chapter II: Do Market Risk Management Techniques Amplify Systemic Risks? Global Financial Stability Report (October).

Jobst, A. (2012) Systemic risk in the insurance sector-A review of general issues and some findings on large insurers in Bermuda, working paper, Bermuda Monetary Authority, Hamilton, Bermuda.

Kaufmann, G. G., and Scott, K. E. (2003) 'What is systemic risk, and do bank regulators retard or contribute to it?’ Independent Review 7(3): 371-391.

Keller, P. (2011) 'Solvency II and incentives for systemic risk exposure’, Progres No. 54.

Kessler, D. (2013) 'Why re(insurance) is not systemic', Journal of Risk and Insurance advance online publication 21 July, doi: 10.1111/j.1539-6975.2013.12007.x.

Klein, R. W. (2011) Insurance market regulation: Catastrophe risk, competition and systemic risk, working paper, Georgia State University, Atlanta, GA.

Klein, R. W. (2012) 'Principles for insurance regulation: An evaluation of current practices and potential reforms', Geneva Papers on Risk and Insurance-Issues and Practice 37(1): 175-199. 
Klein, R. W. (2013) 'Insurance market regulation: Catastrophe risk, competition and systemic risk', in Dionne, G. (Ed.), Handbook of Insurance, $2^{\text {nd }}$ edition, New York: Springer, pp. 909-939.

Knight, F. H. (1921) Risk, Uncertainty and Profit, Chicago, IL: Chicago University Press.

Kress, J. C. (2011) 'Credit default swaps, clearinghouses, and systemic risk: Why centralized counterparties must have access to central bank liquidity', Harvard Journal of Legislation 48(1): 49-93.

Lehmann, A. P., and Hofmann, D. M. (2010) 'Lessons learned from the financial crisis for risk management: Contrasting developments in insurance and banking', Geneva Papers on Risk and Insurance-Issues and Practice 35(1): 63-78.

Liedtke, P. M. (2010) 'The lack of an appropriate definition of systemic risk', Insurance and Finance No. 6.

NAIC (2000) Definition of Insurance Working Group White Paper (September).

Neale, F. R., Drake, P. P., Schorno, P., and Semann, E. (2012) Insurance and interconnectedness in the financial services industry, working paper, UNC Charlotte, Charlotte, NC.

Oxera (2007) Insurance Guarantee Schemes in the EU (November).

Park, S. C., and Xie, X. (2014) 'Reinsurance and systemic risk: The impact of reinsurer downgrading on property-casualty insurers', Journal of Risk and Insurance advance online publication 06 June, doi: 10.1111/jori.12045, 1-35.

Radice, M. P. (2010) Systemische Risiken im Versicherungssektor? working paper, FINMA.

Rejda, G. E., and McNamara, M. J. (2014) Principles of Risk Management and Insurance, $12^{\text {th }}$ edition, Harlow, UK: Pearson.

Rodríguez-Moreno, M., and Peña, J. I. (2013) 'Systemic risk measures: The simpler the better?', Journal of Banking \& Finance 37(6): 1817-1831.

Schwartz, R. F. (2007) 'Risk distribution in the capital markets: Credit default swaps, insurance and a theory of demarcation', Fordham Journal of Corporate \& Financial Law 12: 167-201.

Swiss Re (2008) 2007 Annual Report (February).

Taylor, A. M. (2012) 'Global financial stability and the lessons of history: A review of Carmen M. Reinhart and Kenneth S. Rogoff's “This time is different: Eight centuries of financial folly",' Journal of Economic Literature 50(4): 1092-1105.

Tarashev, N., Borio, C., and Tsatsaronis, K. (2010) Attributing systemic risk to individual institutions, working paper, Bank for International Settlements, Basel.

Trichet, J. C. (2005) 'Financial stability and the insurance sector', Geneva Papers on Risk and Insurance-Issues and Practice 30: 65-71. 
Tversky, A., and Kahneman, D. (1992) 'Advances in prospect theory: Cumulative representation of uncertainty', Journal of Risk and Uncertainty 5(4): 297-323.

Van Lelyveld, I., Liedorp, F., and Kampman, M. (2011) 'An empirical assessment of reinsurance risk', Journal of Financial Stability 7(4): 191-203.

Vaughan, T. M. (2009) 'The economic crisis and lessons from (and for) U.S. insurance regulation', Journal of Insurance Regulation 28(1): 3-18.

Weiß, G. N. F., Bostandzic, D., and Irresberger, F. (2013) Catastrophe bonds and systemic risk, working paper, Technische Universität Dortmund, Dortmund.

Weiß, G. N. F., and Mühlnickel, J. (2013) Consolidation and systemic risk in the international insurance industry, working paper, Technische Universität Dortmund, Dortmund.

Weiß, G. N. F., and Mühlnickel, J. (2014) 'Why do some insurers become systemically relevant?’ Journal of Financial Stability 13: 95-117.

Weiß, G. N. F., Neumann, S., and Bostandzic, D. (2012), Systemic risk and bank consolidation: International evidence, working paper, Technische Universität Dortmund, Dortmund.

Zufferey, J. B. (2000) 'Finanzmarktregulierung und -aufsicht in der Schweiz', from http://www.efd.admin.ch/dokumentation/zahlen/00578/00854/index.html?lang=de, accessed 19 October 2012.

Zweifel, P., and Eisen, R. (2012) Insurance Economics, $1^{\text {st }}$ edition, Heidelberg, Germany: Springer. 